\title{
EL SENTIR POPULAR ANDALUZ REFLEJADO EN LA CARTELERA TEATRAL ASTIGITANA DE FINALES DEL SIGLO XIX. RESPUESTAS A LA PROBLEMÁTICA SOCIAL ${ }^{1}$
}

\author{
PIEDAD Bolaños DonOSO \\ Universidad de Sevilla
}

«Únicamente la Justicia social podía salvar a los hombres, y la Justicia no era del cielo, sino de la tierra» ${ }^{2}$

\section{RESUMEN}

La cartelera teatral astigitana de finales del siglo XIX (1890-1899), inédita hasta hace unos días, nos ha proporcionado un rico material para el estudio del teatro andaluz de estos años. Los temas que nos ofrecen son muchos y muy ricos, habiendo elegido para este estudio la problemática social y su respuesta, a través de una selección de las obras, siempre que sus autores fueran también andaluces. De esta forma, hemos comprobado si aquello que nos advirtió Victor Hugo, en su prólogo de Cronwell: «...es necesario que la multitud no salga del teatro sin llevarse consigo alguna moralidad austera y profunda» se llevó a la práctica. Este trabajo ofrece una respuesta.

Palabras clave: Temas sociales, Teatro andaluz, Siglo XIX, Cartelera teatral.

\section{THE ANDALUSIAN POPULAR FEELING REFLECTED IN THE LIST OF PLAYS STAGED IN ÉCIJA AT THE END OF THE 19TH CENTURY. ANSWERS TO SOCIAL QUESTIONS}

\begin{abstract}
The list of plays staged in Écija in the late 19th century (1890-1899) —unpublished until very recently - has cast new light on Andalusian drama, as it has provided precious material for the study of the theatre produced at that time. Those plays evolve around a wide range of topics, although only those written by Andalusian authors and dealing with social issues have been selected in this study. The author of this paper has thus been able to check whether Victor Hugo's request in his Preface to Cromwell («...that the audience should not leave the playhouse without carrying some sort of deep, austere morality with them») was actually fulfilled. This article provides an answer.
\end{abstract}

Key words: Social issues, Andalusian theatre, 19th Century, List of plays.

${ }^{1}$ La cartelera teatral con la que trabajo ha sido publicada con el título «Cartelera teatral de Écija (1890-1899)». Signa. Revista de la Asociación Española de Semiótica, 16, 2007. pp. 235-288. Agradezco al Doctor Portillo su colaboración.

${ }^{2}$ BLASCO IBÁÑEZ, Vicente. La bodega. 


\section{INTRODUCCIÓN}

Un lector anónimo, al terminar de leer un ejemplar de la primera edición de la novela La bodega, de Vicente Blasco Ibáñez, anotó lo siguiente: «D. Vicente, usted sirvió para algo» ${ }^{3}$, parecer que, sin duda, no hubiera compartido el protagonista de la obra - Fernando Salvatierra - cuando al final de sus días se encontró viejo, abatido por la soledad y dándose cuenta de que todos sus esfuerzos por mejorar a los suyos no habían servido, aparentemente, para mucho.

No debe extrañar que siendo mi propósito examinar una cartelera teatral (1890-1899), abra este trabajo con la cita de una obra narrativa, aunque contemporánea a aquellos años. Pero la autoridad moral del autor respalda mi decisión pues para Blasco Ibáñez

«La novela — dice— es el género literario más importante de nuestra época (...). De sus páginas se escapa el humo embriagador de la ilusión que nos eleva a otros mundos mejores, o nos inspira el deseo de ser más generosos y más buenos en el mundo presente» ${ }^{4}$.

Y, además, se sabe que la novela realista fue considerada más apta que el drama para expresar los problemas del hombre de su época. Fue una metonimia de la realidad. Por eso tampoco extraña que Clarín reclamara, en 1884, un acercamiento entre el teatro y la novela. Decía así:

«En el teatro hay que distinguir, sobre todo al hablar entre el arte y el espectáculo. El teatro como espectáculo, no decae; por el contrario, en el movimiento de la cultura popular se nota que esta diversión penetra más y más en las necesidades artísticas del pueblo. Pero como obra literaria, pocas veces satisface a los hombres de gusto lo que en estos días producen los dramaturgos contemporáneos (...) Con la novela sucede lo contrario; no tiene espectáculo, es todo arte; el gran público, mejor, el público grande, no la lee siquiera, o la lee y no la entiende (...); pero en cambio, las personas de gusto, las que reflexionan y saben de estas materias, reconocen que la literatura de la actualidad presente, la más propia de la cultura que alcanzamos, es la novela (...). La novela, toda arte y nada más que arte, sigue deleitando a los inteligentes» 5 .

Su preferencia por la novela como el 'vehículo más apropiado que las letras habían escogido’ estuvo clara, pero hubo de ser Galdós con su drama Realidad (1892) el que pusiera en práctica este acercamiento entre los dos géneros, reseñándose por parte de la crítica su profundización en los caracteres 'aptitud propia del novelista'. Así recoge esta idea Antonio Fernández:

\footnotetext{
${ }^{3}$ Ibidem, p. 541.

${ }^{4}$ BLASCO IBÁÑEZ, Vicente. «Discurso en la Universidad George Washington» Madrid: Aguilar, pp. 1345.

5 ALAS, Leopoldo «Clarín». Mezclilla. Texto tomado de Jesús RUBIO. La renovación teatral española de 1900: manifiestos y otros ensayos, pp. 73-76.
} 
«La nueva orientación literaria de Galdós hay que entenderla dentro de sus objetivos de renovar a la vez la novela y el teatro, mediante el acercamiento entre ambos géneros. En su opinión (de Galdós) la novela tendría que buscar una mayor agilidad expositiva de los hechos, prescindiendo de la lentitud y prolijidad derivadas del descriptivismo que había en la narrativa extensa naturalista (...). Y el teatro debería incorporar la capacidad de análisis psicológico de los personajes que tradicionalmente caracterizaba a la novela» ${ }^{6}$.

Gracias a esa corriente de acercamiento que se intentó producir entre novela y teatro a fines del siglo XIX, y aún siendo la novela el género por excelencia en el que se plasma la renovación social, estimo que puede ser interesante examinar esta cartelera teatral inédita para ver cómo esos mismos problemas pudieron ser reflejados en el teatro de la época.

Se ha dicho que todo género literario está mediatizado, por un lado, 'por las leyes del mercado capitalista, y, por otro, por las necesidades y aspiraciones del proletariado emergente'. Y yo me pregunto ¿este 'proletariado' había olvidado tan rápidamente sus raíces? ¿continuó, como si tal cosa, aplaudiendo los temas frívolos que se le presentaban en el escenario queriendo dar la espalda a los problemas sociales existentes sin hacer nada por resolverlos? El pueblo llano no siempre pudo frecuentar el teatro y, cuando lo hizo, trató de divertirse para evadirse de su dura realidad. Los escritores primero y después los empresarios tuvieron en sus manos la oportunidad de denunciar el malestar social y no todos lo hicieron. Ellos sabrán por qué y, como recoge León Roca «...el que calle, debiendo hablar — dice— sabe por qué calla». Pero es muy posible que «en su día, así lo reclama la justicia, se exigirán todas las responsabilidades por acción y también por omisión» ${ }^{7}$. A más de uno de los autores dramáticos andaluces habrá de pasarle factura la Justicia, tanto por acción como - y sobre todo- por omisión.

Tras el examen de esta cartelera teatral inédita que durante los años de 1890 a 1899 (época del Regeneracionismo) se representó en Écija ${ }^{8}$, deberíamos de poder hablar de si este pueblo pudo contemplar sus muchas carencias en las tablas o, por el contrario, todo lo que allí se le representó fue un teatro ajeno a sus problemas vitales. Pero difícil será poder responder a esta

\footnotetext{
${ }^{6}$ FERNÁNDEZ INSUELA, Antonio. «Galdós y el drama social».

${ }^{7}$ ROCA, León. Vicente Blasco Ibáñez, pp. 491-2.

${ }^{8}$ ARCHIVO MUNICIPAL DE ÉCIJA, Libro 1677: «Relación de las obras dramáticas representadas en el Teatro principal de esta Ciudad, durante el trimestre de ... a ...inclusive del presente año, con arreglo al Decreto del 1 de junio de 1886». Así se inician las hojas de cada trimestre, en donde se anotan el número de representaciones, el título de la obra, los autores de la letra y de la música, así como el director de la compañía. Estas relaciones se remitían una vez firmadas al trimestre, al Excmo. Gobernador de Sevilla, por lo que no pudo obedecer su elaboración a la exigencia del citado Decreto que ordenaba que «La autoridad tuviera conocimiento de la representación 24 horas antes de su comienzo» (Cfr. un resumen de este Decreto en PASCUAL MARTÍNEZ, Pedro. «Parlamento y teatro en el siglo XIX». p. 331).
} 
cuestión tan delicada pues el «público» teatral no coincide con el 'pueblo' (=sociedad) astigitano y lo más normal —como comenta José Monleón- es que las clases populares hayan sido muy a menudo representadas «sin formar parte del público, reducida su presencia a las manifestaciones festivas, a sainetes irrelevantes, juguetes cómicos u operaciones populistas» ${ }^{9}$.

Señalemos a priori que nos encontramos ante un mosaico de autores y de géneros: junto a los últimos coletazos del drama romántico se representaron diversas piezas del Género Chico y algunas zarzuelas grandes. En muchas de ellas se recogen pequeños atisbos de crítica social, aún sin haber sido toda la pieza concebida para este fin — como sí ocurrió en la novela- pues es frecuente la tendencia a la fragmentación temática al nutrirse el autor de elementos diversos por tener que atender a diversas exigencias.

Para ir haciendo 'cuerpo' y 'espíritu', citaré unas palabras vertidas por José López Rubio que reflejan cómo responden anímicamente los pueblos ante diferentes estados políticos, para llegar a saber exactamente cuál es la situación de esos años en España, y, por ende, en Andalucía, aunque se puede adelantar que, en teoría y en general, se produjo una disconformidad de la burguesía media y una protesta contra el sistema, surgida del régimen de la Restauración, con la crítica a los partidos que se alternaban. Dice así López Rubio:

«Sabido es que cuando, rara vez, los pueblos llegan a ser felices, o se aproximan mucho, es cuando más desean llorar o estremecerse en el Teatro. Cuando todo es apacible, el llorar en la butaca de una platea o en el asiento de un anfiteatro, viene a resultar una necesidad. El Teatro es una diversión en el verdadero sentido de la palabra. Es en los momentos difíciles cuando se busca la evasión por caminos más plácidos, que consuelan y apacigüen el ánimo» ${ }^{10}$.

No es la última década del siglo XIX, precisamente, una etapa histórica pujante —en el más amplio sentido del término- por lo que esperamos encontrar denunciados en el teatro —al menos en teoría - los derechos que al pueblo se le venían usurpando sistemáticamente. Tendría que ser éste feliz y alegrarse, al menos, al saber que ciertas Instituciones podrían ayudarle a aliviar su dura realidad. Así se lo hacen saber ciertos personajes del episodio nacional Cádiz, como se aprecia seguidamente:

$\begin{array}{ll}\text { MAJO. } & \text { El Congreso, ¿pa qué sirve? } \\ \text { Rubio. } & \text { Pa goberná la nación, } \\ & \text { pa darnos más libertad. } \\ & \text { Ya en España se acabó } \\ & \text { lo de yo soy más que tú. } \\ \text { MAJA. } & \text { ¡Hombre! }\end{array}$

${ }^{9}$ MONLEÓN, José. «El autor y el público», p. 8.

${ }^{10}$ LÓPEZ RUBIO, José. «La Restauración y su teatro», p. 127. 


\begin{tabular}{ll} 
RUBIO. & \multicolumn{1}{c}{ No habrá Inquisición, } \\
CuRRA. & ni privilegios, ni naa. \\
RUBIO. & Pueso ¿cómo se arregló? \\
MAJO. & ¿Y qué es eso? \\
RUBiO. & La cuestión \\
& de los derechos del pueblo ${ }^{11}$.
\end{tabular}

Se señala el año de 1895, fecha del estreno de Juan José de Joaquín Dicenta, como el momento más significativo para el inicio del teatro con tema social, aunque ya en 1855 se estrenara Un día de Revolución de Fernando Garrido, obra considerada como el primer exponente de este teatro, al igual que, algunos años más tarde -1880 - y de forma más continuada, aparecieran indicios de propuestas renovadoras al reflexionar sobre el agotamiento de ciertas formulas dramáticas decimonónicas y empezar los autores la búsqueda de alternativas. Hubo de suceder tal como comenta Jesús Rubio: «El trayecto recorrido va del realismo burgués al inicio de las vanguardias. De la creencia en la posibilidad de representar miméticamente sobre los escenarios la vida humana con toda su complejidad, al reconocimiento de las limitaciones de esta representación y su artificialidad intrínseca» ${ }^{12}$.

En el apartado siguiente se podrá comprobar cómo los problemas sociales que acuciaban a la sociedad española en esa época fueron muchos y, quizás en Andalucía, algunos más. Por esta razón y viendo el número de obras representadas, pensé delimitar el trabajo y seleccioné — para su lectura- a los autores andaluces allí presentes ${ }^{13}$, pues supuse que ellos tendrían que estar más

\footnotetext{
${ }^{11}$ BURGOS, Javier de. Cádiz. El baile de Luis Alonso, p. 190.

${ }^{12}$ RUBIO JIMÉNEZ, Jesús. La renovación teatral española de 1900..., op. cit., p. 22.

${ }^{13}$ Son los siguientes, por orden alfabético: Hermanos ÁLVAREZ QUINTERO, Utrera (Joaquín) 1873-1944; (Serafín) 1871-1938; BERMEJO, Ildefonso Antonio, Cádiz, 18201892; BURGOS, Javier de, El Puerto de Santa María, 1840-1902; CUSTODIO, Ángel, Écija, (¿?); FERNÁNDEZ SHAW, Carlos, 1865-1911; GARCÍA DE CASTRO Y RÍO, Clemente, Osuna, 1861-1915; GUERRA MOTA, Luis Domingo, Sevilla, 1857-1929; GUTIÉRREZ DE ALBA, José María, Alcalá de Guadaira, 1822-1897; JACKON VEYÁN, José, Cádiz, 1852-1935; JIMÉNEZ PRIETO, Diego, Arjona, (¿?)-1907; MACARRO, Francisco (¿?), (¿?)-1907; MONTESINOS LÓPEZ, Eduardo, Sevilla, 1869-1930; MOTA Y GONZÂLEZ, José, Sevilla, 1836-1900; OLONA Y GAETA, Luis, Málaga, 1823-1863; ORTIZ DE PINEDO, Manuel, Aracena, 1831-1901; PÉREZ Y GONZÁLEZ, Felipe, Sevilla, 1854-1910; PERRÍN Y VICO, Guillermo, Málaga, 1857-1923; PINA DOMÍNGUEZ, Mariano, Granada, 1840-1895; SÁNCHEZ Y CASTILLA, Eduardo, Cádiz, (¿?)-1899; SANZ PÉREZ, José, Cádiz, 1818-1870; TIRADO NARIO, Juan de la Cruz, Sevilla, 18121891; VALDELOMAR Y FÁBREGUES, Enrique, Córdoba, (¿?)- 1897. Para la identificación de las obras nos hemos servido de los catálogos siguientes: RODRÍGUEZ SÁNCHEZ, Tomás. Catálogo de dramaturgos españoles del siglo XIX. Madrid: Fundación Universitaria Española, 1994; y ROMERO FERRER, Alberto. Catálogo de autores dramáticos andaluces: 1800-1897, 2 vols., VARGAS-ZÚÑIGA, Lola (dir.) y BAJO MARTÍNEZ, María Jesús. (coord.), Sevilla: Consejería de Cultura/Centro de Documentación de las Artes Escénicas de Andalucía, 2002.
} 
acertados al denunciar una realidad tan cercana, proponiendo soluciones, como lo teorizó Bertolt Brecht y que expresó con estas palabras:

«El escritor que ha descubierto, a la vez, la miseria social del mundo y que este mundo es transformable, no puede escribir cualquier cosa, de cualquier modo y para cualquiera. Tampoco puede contentarse con describir el mundo, sino que tiene que ayudar a cambiarlo» ${ }^{14}$.

Veamos si así sucede. Hemos examinado un total de 43 obras (aunque son bastantes más las representadas por los autores andaluces). Algunas de ellas fueron repuestas en varias ocasiones (por ejemplo, Certamen Nacional, de Guillermo Perrín Vico, con siete reposiciones; La cruz blanca, del mismo autor, con cuatro; la misma suerte corrió La Restauración, de Felipe Pérez González, con otras tantas veces), aunque lo normal es que se repusiera una sola vez y desapareciera durante bastantes años de la programación. Muchas de ellas no volvieron jamás a los escenarios. Hay autores andaluces muy poco conocidos con una escasa presencia en la cartelera, y otros que la fama les acompañó durante toda su vida, como fueron los hermanos Quintero, Javier de Burgos o Mariano Pina Domínguez. Cada uno de ellos pertenece a una época diferente — de aquí que podamos hablar de un 'mosaico' de programación- y era de esperar que los más mayores no pudieran estar inmersos en esa corriente renovadora que se produjo en el teatro a partir de 1880 .

Sin embargo, este benévolo juicio no se le puede aplicar a todos los empresarios o 'programadores' pues, movidos por sus intereses económicos, se amparan en obras excesivamente 'viejas' en comparación con la extensa producción de nuestros dramaturgos, pudiendo haber elegido obras mucho más recientes. Lo que sí es cierto, es que hubo de tener el teatro de Écija algunos buenos empresarios pues, en bastantes ocasiones nada más estrenarse la obra en Madrid, se repuso en esta ciudad. Para concluir esta introducción, decir que esperamos haber descubierto alguna obra que hasta el presente no se le había adjudicado a su autor en ningún Catálogo, ni en las Bases de datos de tantas bibliotecas como he revisado. Como botón de muestra Las pesquisas de Patricio, de Ildefonso Bermejo (1890).

\section{II. ÉCIJA Y SU AMBIENTE SOCIO-POLÍTICO}

A mediados del siglo XIX, Écija, al igual que todo el país, está inmersa en una situación social y política inestable, con continuas tensiones entre los partidos y que, a nivel de Estado, acabará con el destronamiento de la reina Isabel II en septiembre de 1868. Los enfrentamientos entre librepensadores

${ }^{14}$ Palabras tomadas del estudio realizado por CASTELLÓN, Antonio. El teatro como instrumento político en España (1895-1914). Madrid: Textos Universitarios, Endimión, 1994, p. 18 . 
(liberales) y tradicionalistas (conservadores), entre obreros y patronos, están al orden del día.

Según recoge Fernando del Pino, en el «censo de 1860, Écija tenía por esta fecha una población de 27.216 habitantes» ${ }^{15}$, cifra nada despreciable. Es de suponer que los grupos sociales altos (profesionales liberales: abogados, escribanos públicos, procuradores, médicos...) fueron los que tuvieron mayor índice de renta y, por ende, un mejor acceso a la cultura, tanto para leer como para disfrutar del teatro. También se conoce que el índice de analfabetismo era elevado. Todavía en 1901, el $61 \%$ de la población no sabía ni leer ni escribir, hecho que no impide que parte de este grupo social acudiera habitualmente o de forma esporádica al teatro, pues este género tiene esa ventaja.

Pero lo más llamativo de todas estas cifras es que, al menos, el $30 \%$ de la población española, en 1868, dependía de los jornales de la tierra. Constata el estudioso Del Pino, cómo «esta situación de penuria se hace especialmente dura en Écija y su comarca y se verá reflejada en 'nuestro periódico' (el que está examinando) a través de editoriales y artículos» ${ }^{16}$. Se hace más patente este juicio si leemos a Antonio Pereyra y Real, dueño del periódico La Juventud, quien escribió así en el editorial del 27 de febrero de 1868:

«La tempestad más espantosa que puede efectuarse en los horizontes de los pueblos, es sin duda alguna la que produce la falta de recursos en la clase obrera, su explosión es mucho más temible que la explosión del rayo, y si no fuera contenida causaría más desastres y trastornos que cualquier terremoto por grande que este fuere» ${ }^{17}$.

Invito a la lectura de este artículo pues se reconocerá, en las palabras del autor, auténtica desolación. Se nos habla de miseria, hambre y penurias que estaban sufriendo los obreros, pues según la opinión de otro contemporáneo - José María Giles y Rubio- (aparecida en el mismo número que el del citado Pereyra), había «de cuatro a seis mil hombres implorando la caridad pública en demanda de trabajo o de alimento para ellos y sus familias» ${ }^{18}$.

Sin duda que los hacendados, poseedores de los grandes cortijos y olivares encontraron en esta época —época de hambre y miseria- su mejor aliada para acrecentar su caudal, pues nada más que ella le facilita los esclavos del jornal. Aún quedaba mucho camino por recorrer en los campos astigitanos para que sus jornaleros pudieran compartir la opinión de Fernando Salvatierra - protagonista de La bodega- cuando decía que:

${ }^{15}$ PINO JIMÉNEZ, Fernando del. «Sobre la Juventud. Revista ecijana de intereses materiales, ciencias, literatura y costumbres. Enero-julio de 1868». En: Écija en la Edad Contemporánea. Actas del V Congreso de Historia. Écija: Excmo. Ayuntamiento, 2000, pp. $247-$ 258 ; p. 249.

16 Ibidem, p. 250.

17 Ibidem.

${ }^{18}$ La Juventud. 27 de febrero de 1868, p. 45. 
«Los hombres comenzaban de nuevo su marcha hacia la fraternidad: el ideal de Cristo; pero abominando de la mansedumbre, despreciando la limosna por envilecedora e inútil. A cada cual lo suyo - decía-, sin concesiones que denigran ni privilegios que despiertan el odio. La verdadera fraternidad era la Justicia social» ${ }^{19}$.

Blasco Ibáñez redactó su novela teniendo como referente el asalto de Jerez, que tuvo lugar el 8 de enero de $1892^{20}$. En Écija, el 6 de febrero de ese mismo año se publica, en el n. ${ }^{\circ} 4$ de La Alianza. Periódico Republicano ${ }^{21}$, un artículo/editorial titulado «Verdades al desnudo», que concluye en el número siguiente aparecido el 13 de febrero de ese mismo año. Lo firma Manuel Marín quien reflexiona sobre los acontecimientos de Bilbao y Jerez, asegurando que «...a unos han causado pavor, a otros le han infundido lástima». Dice pretender examinar lo sucedido resaltando «...los males que afligen a la actual sociedad, no sin antes echar una mirada retrospectiva por el campo de la historia». ¡Y vamos que si la echa! Dice verdades como que «la tendencia a vivir a costa del trabajo ajeno es tan antigua como la sociedad misma...». O que «la tendencia al disfrute de una vida plácida inclinó el ánimo del hombre fuerte para hacer esclavo a su hermano débil...». Muchas son las razones históricas que el hombre tuvo para sublevarse, y

«hoy, que no es la mano negra la que presta aliento al esclavo disfrazado de nuestra época; pero que en cambio tiene fe y se organiza bajo los auspicios de la mano negra, embotados sus sentimientos por la desesperación del eterno martirio y turbadas las facultades por el dolor que produce el hambre, nuestro obrero empieza a dejar traslucir que desprecia la existencia y se dispone a entrar en una nueva faz de vida» ${ }^{22}$.

En la segunda parte del artículo (n. $\left.{ }^{\circ} 5\right)$ y en donde concluye, no sólo examina el padecimiento moral, sino que se adentra en su visión bajo el punto de vista social. Y se pregunta

«¿En qué se diferencia el obrero de hoy del antiguo esclavo? En que no se le fustiga con el látigo, ni se le sujeta a bárbaros castigos, pero en cambio ha de prestarse a echar los bofes trabajando y ha de tolerar que añadan al día alguna hora de la noche, porque de protestar se le amenaza con despedirle que equivale a condenarle a las torturas del hambre» ${ }^{23}$.

${ }^{19}$ BLASCO IBÁÑEZ, Vicente. La bodega, op. cit., p. 392.

${ }^{20}$ A lo largo de los últimos cincuenta años del siglo XIX se produjeron varios levantamientos de los campesinos andaluces. Recordemos, por ejemplo, el que hubo en Loja en 1861 (Cfr. ARIAS CASTAÑÓN, Eloy. «El contexto político de España en el Siglo XIX». En: Actas del Simposio Nacional. Literatura y Política en el siglo XIX. José María Gutiérrez de Alba. Sevilla: Centro Andaluz del Libro, 1998, pp. 15-50).

${ }^{21}$ El análisis exhaustivo de este periódico está hecho por ARIAS CASTAÑón, Eloy. «Republicanismo y autonomía. Periódico La Alianza de Écija (1892-1893)». En: Actas del III Congreso sobre el Andalucismo Histórico. Sevilla, 1989, pp. 651-668.

${ }^{22}$ La Alianza, n. ${ }^{\circ}$ 4, pp. 1-2.

${ }^{23}$ Ibidem, n. ${ }^{\circ}$ 5, p. 1. 
No parecen necesarios más detalles para patentizar la situación desesperada en la que se tenía que encontrar un alto porcentaje de la población astigitana. Y como buen crítico, Manuel Marín, el autor de estos artículos, proponía la necesidad de reformas sociales pues — dice-

«las revoluciones nadie las organiza ni encauza; ellas se imponen y estallan sin saber dónde, cómo ni por qué. Parece que una mano providencial las dirige y que una fuerza extraña les presta aliento. Cuando abortan, arrollan y destruyen, cual irresistible tromba, todo en orden de intereses y hasta la manera de ser y vivir de muchas naciones» ${ }^{24}$.

Más de una y de dos rebeliones tuvieron que fracasar; de aquí que, el personaje literario de D. Luis, en La bodega, pudiera afirmar que:

«...él sabía que lo que deseaban los trabajadores eran utopías (...) y que todo lo que ocurría era por culpa de los gobiernos, que no meten en cintura a los gañanes, y también por falta de religión. Sí señor, la religión: éste era el freno del pobre; y como cada vez había menos, los de abajo, con el pretexto del hambre, querían comerse a los de arriba» ${ }^{25}$.

No es mi intención continuar con el examen de la prensa astigitana para seguir comprobando cómo en sus páginas se recogen otros muchos pareceres de semejante naturaleza. Haría falta y es cierto, el gran estudio de conjunto de esta prensa local pues, como indicó María del Carmen Simón Palmer «podemos hablar de esta prensa local como fundamento para conocer con exactitud la sociedad del momento» ${ }^{26}$.

Por lo vertido en uno de estos periódicos y por lo que imaginamos, estamos en condición de aventurar que era necesario y urgente practicar reformas sociales para facilitar al pueblo una vida más digna.

Las primeras reformas sociales las reflejó programáticamente la primera República -11 de febrero de 1873/diciembre del mismo año- cuyos ideales les llevó por ser representativa, laica y reformista. Aglutinaron a mucha gente entre sus filas, y, como dice Manuel Súarez Cortina, «El proyecto republicano disponía del apoyo de sectores de las burguesías industrial y comercial, incluso de una base rural nada desdeñable» ${ }^{27}$. Ellos fracasaron como pro-

24 Ibidem

${ }^{25}$ BLASCO IBÁÑEZ, Vicente. La bodega, op. cit., pp. 278-279.

${ }^{26}$ SIMÓN PALMER, María del Carmen. «La prensa local como fuente de la 'pequeña' historia». En: La prensa española durante el siglo XIX. Almería: Instituto de Estudios Almerienses, 1987. Los periódicos astigitanos, desde 1881 hasta 1899, por orden de aparición, fueron los siguientes: El cronista Ecijano (1881-1890); El Eco de Écija (1883-1890); El Constitucional (1888-1892); La opinión Astigitana (1890-1925); La ciudad del sol (1890); El Liberal Ecijano (1891); La Alianza (1892); El Liberal (1892); El Ciclón (1892); La coalición Liberal (1894); Écija, Fin de Siglo (1899).

27 SUÁREZ CORTINA, Manuel. El gorro frigio. Liberalismo, Democracia y Republicanismo en la Restauración. Madrid: Biblioteca Nueva. Sociedad Menéndez Pelayo, 2000, pp. 22-23. 
yecto político en España, aunque no así en la Écija republicana en donde gobernaron «hombres rudos en cuanto su instrucción, por pertenecer a la clase jornalera» ${ }^{28}$. Sus máximas, como la renovación educativa, la educación popular (instrucción del obrero, de la mujer y de los sectores sociales más desprotegidos), no cayeron en saco roto. 'El maestrico' fue muy consciente del poder que tenía un pueblo educado (La bodega), por lo que preguntó retóricamente a Salvatierra: «El mundo es del que más sabe, ¿verdad, don Fernando? Si los ricos son fuertes y nos pisan y hacen lo que quieren, no es solamente porque tienen dinero, sino porque saben más que nosotros...» ${ }^{29}$.

Pero no sólo hay que recordar la educación popular como reforma social prioritaria «asentada sobre el valor y el esfuerzo individual, antes que sobre castas cerradas» ${ }^{30}$, sino que ya en 1871 Nicolás Salmerón había apoyado los derechos de los trabajadores a asociarse para así defender mejor sus intereses $^{31}$. Será otro de los éxitos logrados por la reforma social preconizada por los republicanos, siendo su mejor exponente el reformista Gumersindo de Azcárate que, en 1881, dejó escrito el ideario social de su grupo en el libro Resumen de un debate sobre el problema social ${ }^{32}$. «El ideario armónico como sustituto del antagonismo en las relaciones entre capital y trabajo, la cooperación, el asociacionismo, la defensa de los sindicatos como portavoces del trabajo y su gestión a favor de los trabajadores, constituyó — dice Suárez Cortina- la base de la reforma social defendida por Azcárate» ${ }^{33}$.

Los años pasan y los hombres se renuevan en el partido Reformista. Y hay que esperar hasta 1912 para que Melquíades Álvarez plasme por escrito las ideas diseñadas por su partido y para que nosotros podamos saber, en concreto, las reivindicaciones sociales que, por aquellos años, defienden.

«Predicaremos para la mejor conciencia de los derechos y deberes del pueblo, una Constitución social más justa, equitativa y racional que la presente; predicaremos y realizaremos, sin destruir el principio de la propiedad individual, la exigencia de que vayan convirtiéndose en propiedades colectivas muchos elementos de producción que, como las minas y los ferrocarriles, tienen una importancia princi-

${ }^{28}$ GONZÁLEZ FERNÁNDEZ, Ángeles. «Una aproximación a los movimientos sociales en la Andalucía rural: Écija, 1900-1924», Écija en la Edad Contemporánea. En: Actas del $V$ Congreso de Historia. Écija: Excmo. Ayuntamiento de Écija, 2000, pp. 461-479, p. 462. Es un excelente trabajo para conocer la tendencia política de Écija en la época en que hemos localizado nuestro estudio por presentar la autora una introducción espléndida sobre la inclinación de las clases populares de finales del siglo XIX hacia el republicanismo.

${ }^{29}$ BLASCO IBÁÑEZ, Vicente. La bodega. op. cit., p. 329.

${ }^{30}$ SUÁREZ CORTINA, Manuel. El gorro frigio..., op. cit., p. 108.

${ }^{31}$ Este período de la historia de Écija está perfectamente estudiado por ARIAS CASTAÑÓN, Eloy. En su trabajo «Écija (1868-1874). De la revolución a la I República: aspectos de la vida política». En: Actas del I Congreso sobre Historia de Écija. Écija: Excmo. Ayuntamiento, 1989, pp. 329-375.

${ }^{32}$ GRAS Y CÍA. Madrid, 1881.

${ }^{33}$ SUÁREZ CORTINA, Manuel. El gorro frigio..., op. cit., p. 152. 
palmente social; pediremos al Estado que fomente las cooperativas, los sindicatos, las sociedades mutualistas y las Bolsas de trabajo; reclamaremos que se lleve a las leyes el derecho de asistencia, que es una de las manifestaciones más grande de solidaridad humana; el seguro a favor de los ancianos; el seguro contra el paro forzoso y exigiremos pensión para los viejos e inútiles cuyos servicios (...) contribuyen al engrandecimiento de su país» ${ }^{34}$.

Finalmente conocemos medidas concretas sociales que pudieran estar en la mente de los trabajadores y son ésas las que nosotros iremos revisando en nuestras obras de teatro para comprobar el grado de conocimiento y/o cumplimiento que se hizo de las mismas. Pueden resumirse en los siguientes puntos:

a) educación general para las clases más necesitadas ${ }^{35}$.

b) asociacionismo para la defensa de los intereses del más débil ${ }^{36}$.

c) cooperativas, sociedades mutualistas y bolsas de trabajo.

d) asistencia sanitaria para todos.

e) pensión para los jubilados.

f) salario social para los más necesitados.

\section{CARTELERA TEATRAL ASTIGITANA: 1890-1899}

Casi todos los autores dramáticos que vamos a examinar, aunque pertenecen a etapas literarias diferentes — según hemos dicho- ejercen el periodismo. Como afirma Marta Palenque:

«...la literatura termina convirtiéndose en un trampolín para llegar a la política, mientras el ejercicio del periodismo es la senda hacia la popularidad y facilita la

${ }^{34}$ ÁLVAREZ, Melquíades. «Discurso-Programa del Partido Reformista». Gijón: El Noroeste, 12-IV-1912.

${ }^{35}$ En Écija, desde 1847 se contó con una Escuela Pública, ubicada en el convento desamortizado del Carmen Descalzo. El mal estado del edificio hizo que el Gobierno Municipal encargara, el 20 de agosto de 1862, a Balbino Marrón y Ranero, arquitecto provincial, un proyecto para realizar un nuevo edificio para acoger de nueva planta un colegio para los niños. Balbino murió el 20 de junio de 1867 y no llegó a realizarlo. Tampoco lo llevó, después de su muerte, nadie a cabo. (Cfr. MEJÍAS ÁLVAREZ, Jesús. «Ideas arquitectónicas de Balbino Marrón y Ranero en Écija: su proyecto de escuelas para niños». En: Écija en Edad Contemporánea..., op. cit., pp.149-156).

${ }^{36}$ La primera asociación contemporánea existente en Écija fue el Casino de Artesanos, creada en 1862. Se constituyó como entidad de recreo e instrucción destinada a las clases medias y al artesanado conforme a una inspiración demócrata que evolucionó hacia el republicanismo federal en el año de la I República. El carácter interclasista y republicano se mantuvo a lo largo de los años siguientes, como lo demuestra el hecho de que en los años ochenta gran parte de sus socios fueran artesanos y empleados. En 1916, el republicano Manuel Barrios Jiménez fue elegido Secretario de la directiva (Cfr. SORIA GONZÁLEZ, A. Pequeña historia del Casino de Artesanos de Écija. Écija, 1982 y GONZÁLEZ FERNÁNDEZ, Ángeles. «Una aproximación a los movimientos sociales...», art. cit., pp. 463-464). 
subida hacia las dos metas: prestigio literario y protagonismo político (...). Este camino no responde sólo a una vocación (...) sino, también, a una ambición muy real y práctica (...). Literatura y política eran beneficios complementarios, porque coadyuvan en la consecución de fama, prestigio y dinero» ${ }^{37}$.

Y, a lo que parece, uno de los géneros literarios más lucrativos fue el teatro.

La documentación con la que trabajamos sólo nos da el nombre de la pieza teatral, sin mencionar para nada el género al que pertenece, ni el día en que se representó ni cómo se configuró la función. Este último dato hubiera sido importante pues, al igual que ocurrió en el teatro del Siglo de Oro y en menor medida, en el del XVIII, una función engloba varias piezas de características muy diversas: desde la comedia/tragedia, a los sainetes, ópera, bailes... ${ }^{38}$. No es que este hecho condicione excesivamente nuestro análisis, pues al fin $\mathrm{y}$ al cabo todas esas obras las presenciaron - sean mayores o menores (de acompañamiento)_, pero es de suponer que el empresario programara según lo acostumbrado teniendo en cuenta la duración de las mismas. Y, sobre todo, mezclando los géneros para agradar al máximo número de espectadores posibles.

La mayor parte del repertorio aquí seleccionado corresponde a obras del género chico $^{39}$, donde predomina lo popular, las costumbres andaluzas, así

${ }^{37}$ PALENQUE, Marta. «El escritor y la política en el siglo XIX». En: Literatura y política en el siglo XIX...., op. cit., pp. 67-81; pp.70-71.

${ }^{38}$ Son muchos los ejemplos que podríamos referir para apoyar mis palabras. Por citar un ejemplo sevillano, les remito al trabajo de los compañeros REYES PEÑA, Mercedes de los y REYES CANO, Rogelio. "Algunas muestras de la relación 'Política-teatro' durante el sexenio absolutista en Sevilla (Datos para una historia del teatro en Sevilla en el siglo XIX)», Archivo Hispalense, 2 época, (1984), n. ${ }^{\circ}$ 206, pp. 41-62; p. 46 y 57. Igualmente se puede ver cómo la compañía de Federico Terol que actuó desde finales de 1874 hasta 1880 por el sureste de España, su 'gran' función consistía en una sinfonía, una obra de tres o más actos y una obra de un acto (Cfr. BOTREL, Jean-François. «El teatro en provincias bajo la Restauración. Un medio popular de comunicación». Bulletin Hispanique, vol. 79 (1982), pp. 381393; p. 383). También, y en una época contemporánea al periodo que estamos analizando, en Calahorra, en 1899, la temporada de verano se abrió el viernes, día 9 «con la zarzuela en un acto de Arniches y Celso Lucio con música del Maestro Caballero El cabo primero, más otra zarzuela de los mismos autores y música de los Maestros Valverde y Torregrosa, Los Puritanos, para cerrar con el estreno del sainete lírico de costumbres madrileñas, en un acto, en prosa, de Carlos Arniches y música de Torregrosa El santo de la Isidra». (Cfr. MARTÍNEZ SAN CELEDONIO, Félix Manuel, y RINCÓN ALONSO, María Jesús del. El teatro en Calahorra. Calahorra, 2002, pp. 38-39).

${ }^{39}$ No debemos olvidar que Bretón de los Herreros «se ve sustituido, (...) en el comienzo de la Restauración, por Javier de Burgos, Ramos Carrión, Vital Aza, Miguel Echegaray y no pocos mas» según recoge LÓPEZ RUBIO, José. «La Restauración y su teatro». En: $L a$ Restauración Monárquica de 1875 y la España de la Restauración, op. cit., pp. 119-136; p. 124. Según dice Marieta Cantos «el público gaditano, en general, debía gozar principalmente del teatro cómico y, especialmente en su forma breve: desde el siglo XVIII el sainetista Juan Ignacio González del Castillo era el máximo exponente de esta tradición, por lo que no es de extrañar que en Cádiz tuvieran tal aceptación las piezas del 'género andaluz', a lo 
como el lenguaje, hecho que permite pensar que, o estamos ante un tipo de función muy de moda en otras tierras, como pudo ser el teatro por horas ${ }^{40}$, al que el público podía asistir cada hora y a la obra que más le apeteciera; o, muy al contrario, - que también sería posible- que hemos renunciado a priori inconscientemente (al no ser obras escritas por autores andaluces), al examen de las obras mayores o extensas que serían las que conformaran el grueso de la programación. En los años 90 un tipo de teatro excluye - por eliminaciónal otro. Al menos así sucede en Madrid siendo para nosotros, por ahora, una incógnita lo que ocurrió exactamente en Écija.

Para abordar mejor nuestro análisis, he repartido el corpus de obras citadas en décadas, de acuerdo con la fecha de su estreno, siendo las más antiguas el sainete Los celos del tío Macaco (1846), de José Sanz Pérez ${ }^{41}$ y el 'drama andaluz' Diego Corrientes (1848) del alcalareño José María Gutiérrez de Alba ${ }^{42}$, ambas pertenecientes a la década de los 40.

Sanz Pérez fue uno de esos autores que mejor supo retratar a la baja clase social andaluza, tal como nos lo deja ver en el tío Macaco, trasquilador, o con Juan Palomo, contrabandista. La presencia del Marqués —otro de los personajes - pretendiendo comprar los amores de Foloseta, canastillera, pone en evidencia y le permite contrastar los modales sencillos y populares del primer grupo de personajes, frente a los arrogantes del segundo. Hemos de resaltar, como primera característica de los autores andaluces examinados, la denuncia de las clases sociales: nobles y 'señoritos' salen muy mal parados. Oigamos un diálogo entre Foloseta y el Marqués:

MARQUÉS. ¿Pues qué más quieres, gitana?

Sales de la pobreza ;oh! te arranco de la miseria, de esa vida de dolor, de trabajos y de infamia, de delitos, de baldón;

que tendría que añadir que no sólo el gaditano, sino el andaluz, en general. Pero el gusto por estas piezas se irá extendiendo por toda la geografía española, como veremos en el apartado «IV. Comparación con otras ciudades españolas» (CANTOS, Marieta. «El teatro breve gaditano a mediados del siglo XIX; algunas piezas andaluzas de José Sanz Pérez». En: casticismo y Literatura en España. PÉREZ-BUSTAMANTE, Ana Sofía y ROMERO FERRER, Alberto (eds.); VÁZQUEZ RECIO, Nieves (col.). Cádiz: Servicio de Publicaciones, 1992 (Cuadernos Draco, n. ${ }^{\circ}$ 1), pp. 99-116; p. 103).

${ }^{40}$ ESPÍN TEMPLADO, María Pilar. El teatro por horas en Madrid (1870-1910). Madrid: Instituto de Estudios Madrileños / Fundación Jacinto e Inocencio Guerrero, 1995.

${ }^{41}$ Los celos del tío Macaco. Pieza en un acto y en verso. Original de... Cádiz: Imprenta de la Revista Médica, 1860. Parece ser que en esta misma imprenta se hizo otra edición en 1850. Fue estrenada en Cádiz, el 27 de abril de 1846, en el teatro Balón: «Hoy se ejecutará el aplaudido drama de los señores García Dondel y Valladares, 4 actos y en verso, titulada Las travesuras de Juana. Se bailará la Jota a seis. Terminando la función el gracioso juguete cómico andaluz, nuevo y escrito en verso por D. José Sanz Pérez, titulado Los celos del Tío Macaco. A las 6» (CANTOS, Marieta. «El teatro breve gaditano...», art. cit., p. 105). 


$\begin{array}{ll} & \text { y te levanto del cieno } \\ \text { Fola clara luz del sol. } & \text { (¿Que me jamen los chusqueles } \\ \text { si no le endiño al gachó!). } & \text { Se quiebre usté y se malisie, } \\ \text { vayasté, ayá, so pendón. } & \\ \text { Fortunita, fortunita } \\ \text { ¡qué delito jise yo? } \\ \text { qué mala estrella sacaste, } \\ \text { probe gitana, ¿porqué, } \\ \text { ¡ay! Maresita, ar nasé, } \\ \text { dime, tú no me ajogaste? } \\ \text { ¿Pa que fuera desgraciá } \\ \text { y anduviera mi probesa } \\ \text { por abajo e la riqueza } \\ \text { como la yerba pisá? } \\ \text { (...) } \\ \text { Mardesío sea er dinero } \\ \text { que da tanto desajogo } \\ \text { pa ofendé....Josú... me ajogo } \\ \text { é corage, cabayero } 43 .\end{array}$

A juicio de José María Gutiérrez de Alba —aún admirando a su maestro Sanz Pérez- el carácter andaluz no había sido reproducido en toda su amplia gama de matices, habiéndose copiado sólo el lado cómico, festivo y a veces grotesco. Para él -y según palabras de José Luis Pérez- «faltaba un cuadro donde se pusiera de relieve la generosidad, el desprendimiento del ser andaluz e, incluso, aquel tipo encarnado en los criminales de profesión, como los bandoleros» ${ }^{44}$. La estrecha relación del 'bandolerismo' como actividad comercial clandestina y las sociedades campesinas, se dieron y se dan la mano, siempre para ayudar a una economía familiar maltrecha. Por eso, este 'tipo' o personaje no es solamente literario - en la saga de José María 'El Tempranillo', 'Jaime el Barbudo' y tantos otros- sino real, reflejándose en él —por parte de la sociedad rural - su rebeldía social, tratando de imponer su propia ley (buena) ante la injusticia de la otra Ley (con mayúscula).

Con Diego Corrientes podemos decir que se abre el recorrido propiamente crítico/social de este trabajo, pues, al pertenecer al período político anterior - monarquía constitucional - nos hacemos buena cuenta del camino que tuvo que recorrer el pueblo español para la conquista de sus derechos sociales.

Diversos son los temas sociales que ya denuncia Gutiérrez de Alba en su obra. El que presenta con más insistencia es el de la falta de distribución de

${ }^{42}$ Diego Corrientes o El bandido generoso. Drama andaluz. En tres actos y en verso, por... Madrid, Imprenta de J. González y A. Vicente, 1848 (Reproducción de la 1. a ed. de 1848 con motivo del Centenario de la muerte de José María Gutiérrez de Alba. PÉREZ MORENO, José Luis (intr.). Sevilla: Fundación El Monte, 1997).

${ }^{43}$ Los celos del tío Macaco, op. cit., pp. 16-17. 
la riqueza (Cfr. Act. I, esc. 3; Act. I, esc. 4; Act. I, esc. 12; Act. III, esc. 4) que es el tema fundamental de la obra:

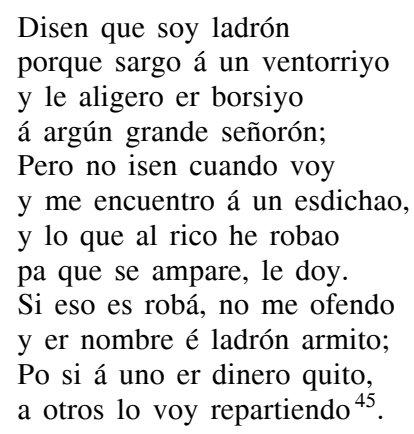

Diego Corrientes no es un peligro para la reforma social demandada por la clase trabajadora. Todo lo contrario. Porque, como decía Fernando Salvatierra, «El que acapara un pedazo de tierra, excluyendo de él a los demás; el que lo entrega a las bestias humanas para que lo haga producir, mientras él permanece ocioso, ese es el que verdaderamente roba a sus semejantes ${ }^{46}$.

Otro tema, aunque tímidamente señalado por José María Gutiérrez de Alba, es el de la falta de educación escolar que tiene el pueblo: los campesinos no saben ni las cuatro reglas (Act. I, esc, 1). Y, por último, la desprotección de la vejez. Es decir, muestra cómo a pesar de los muchos años que tiene una persona, ha de seguir trabajando, pues no existe un Estado que le dé la protección necesaria para cubrirle sus derechos básicos.

\begin{tabular}{|c|c|}
\hline DIEGO. & ¡Cuánta edá tiene usté, agüelo? \\
\hline CHAFAROTE. & $\begin{array}{l}\text { Me paese á mi que me fartan } \\
\text { siete años pa cuatro duros, } \\
\text { si es que mi cuenta no marra, } \\
\text { (...). }\end{array}$ \\
\hline DIEGO. & $\begin{array}{l}\text { ¿Y en qué buscaste la vía } \\
\text { tan viejo y andando á pata? }\end{array}$ \\
\hline CHAFAROTE. & $\begin{array}{l}\text { Jeñó, tengo un borriquillo, } \\
\text { que aunque siego y cojo, anda. } \\
\text { con ér y ese puñao é escobas } \\
\text { me busco er pan pa mi casa } \\
\text { (...). } \\
\text { Y grasias a Dios que ajunto } \\
\text { siquiera pa un potaje é jabas }{ }^{47} \text {. }\end{array}$ \\
\hline
\end{tabular}

\footnotetext{
${ }^{44}$ Diego Corrientes..., op. cit., Introducción, p. XIX.

${ }^{45}$ Diego Corrientes, op. cit., p. 26.

${ }^{46}$ La bodega, op. cit., p. 342.

${ }^{47}$ Ibidem, pp. 24-25.
} 
Por último, denunciar que ya en los años cuarenta del siglo XIX podríamos hablar — por desgracia- de desprotección de la mujer. El varón, siempre más fuerte físicamente que una mujer, aprovecha su superioridad para maltratarla. No hay nada nuevo bajo el sol. El 'Renegado' pretende los amores de Consuelo. Ella lo rechaza y él, para forzarla, toma un trabuco en sus manos y se lo muestra para intimidarla. Consuelo responde:

\section{Porque soy una mugé satrevusté a armá pendencia, ¿siempre es usté tan valiente? ${ }^{48}$.}

Nada más arrancar la década de los cincuenta se estrenó (para unos 'el juguete cómico', para otros 'la comedia') Llueven hijos (1850), de Ildefonso Antonio Bermejo ${ }^{49}$. La acción de esta obra de enredo - donde tres personajes pretenden hacerse pasar por hijos de don Ramiro- se localiza en la Barcelona contemporánea al momento de la escritura de la obra, y en la que se habla de un derecho social tan antiguo como las civilizaciones griega y romana y al que la Iglesia Católica reconoce para los no católicos, como es la facultad de «divorciarse» ${ }^{50}$ ante la imposibilidad de convivencia con la pareja. Don Ramiro dejó un hijo en La Habana, muy niño, a cargo de unos tíos. Éstos han muerto y vuelve el hijo para reencontrarse con sus padres. Pero el enredo de la comedia hace que tres jóvenes quieran hacerse pasar por 'hijos' de don Ramiro. Aburrido de esta situación y turbado por los acontecimientos, discute con su esposa Simona en estos términos:

¿Qué es eso de 'sin embargo'? Si pretendes hacerme padre de esa prole numerosa, entablo desde este instante la demanda de divorcio ${ }^{51}$.

Este derecho que, reconocido en las legislaciones a lo largo de la historia, siempre se había inclinado a favor de los hombres (no siempre la mujer lo podía solicitar), va a ser objeto de materia teatral en varias ocasiones, a lo largo de las obras que estamos examinando, viéndose cómo, a medida que transcurren los años, la mujer será la que tome la iniciativa reflejando la no sumisión de ésta a los caprichos o infidelidades de los hombres. Fue, sin duda,

\footnotetext{
${ }^{48}$ Ibidem, p. 47.

${ }^{49}$ Llueven hijos. Juguete cómico en un acto y en prosa. Original de...Representado con aplauso en el teatro de la Comedia. Segunda edición. Madrid: Imprenta de José Rodríguez, 1861.

${ }^{50}$ En España, ya el Código Civil de 1889 admitió el matrimonio canónico y el puramente civil, para los no católicos, estableciéndose la dualidad de legislaciones en cuanto al divorcio. Unos años antes —en 1884- se dictó la Ley declarativa del divorcio, en la que se recogía que los matrimonios que llevaran más de tres años separados, quedaban divorciados. Por esa razón hubo un considerable aumento de los mismos en ese año y el siguiente. Desde 1886 se ve el aumento progresivo.

${ }^{51}$ Llueven hijos, op. cit., p. 21.
} 
un gran avance para la igualdad de los géneros. Así, Asunción, en la comedia González y González, se presenta en casa del abogado González para denunciar a su marido de una infidelidad «...de aquí el decidirme — dice- a pedir el divorcio ó la separación de cuerpo, que para el caso es igual» ${ }^{52}$. Y Luisa, hija de don Gregorio - en la misma obra- al conocer el engaño en el que ha sido mantenida por su marido, comenta a su padre: « $i E s$ un traidor, un perjuro! Yo quiero separarme». A lo que contesta don Gregorio: «Pero hija, reflexiona que si todas las mujeres engañadas por sus maridos se separasen, no quedaría en España un solo matrimonio...» ${ }^{53}$.

Quedan bien claras las diferencias entre la actitud de don Ramiro en los años cincuenta y ésta última, de los noventa.

Otro personaje, Bermejo, (de la obra que estamos comentando) nos trae a las tablas otro gran problema social. Lleva un rato hablando con su mujer Simona y su cólera ha ido creciendo. Por lo que le llega a espetar:

Lavo mis manos, prohíjalos si te remuerde la conciencia; y si no estás contenta todavía, vete a la inclusa y hazte la madre universal de aquellos inocentes párvulos 54 .

Esta Institución — la inclusa - no era ajena a la población astigitana dado que en esta ciudad se había fundado un centro ya en el año de 1602 donde se recogía a los niños expósitos ${ }^{55}$. El abandono de los niños fue — por desgracia- muy frecuente en aquella sociedad y por aquellos años en los que la mujer, violentada sexualmente por el poderoso, tenía que hacer frente —con los pocos medios económicos de que disponía- a toda la carga familiar. A medida que se consiguen más derechos sociales se respetará a la mujer, otorgándole un trato más de igualdad.

Por estos años se están produciendo los últimos dramas románticos, como fue El terremoto de Martinica (1851) de Juan de la Cruz Tirado y F. Coll ${ }^{56}$, con tal dosis de nacionalismo y patriotismo exaltado, que hubo de hacer llorar ampliamente al auditorio, pero escapa a la proclama que V. Hugo dejó impresa en su prólogo de Cromwell: «...es necesario que la multitud no salga del teatro sin llevarse consigo alguna moralidad austera y profunda» ${ }^{57}$.

${ }^{52}$ González y González. PINA DOMíNGUEZ, Mariano. Comedia en dos actos y en prosa. $2^{\circ}$ edición, Madrid: Sociedad de Autores Españoles, 1899, p. 28.

${ }^{53}$ Ibidem, p. 44.

54 Ibidem.

${ }^{55}$ Cfr. MARTíN OJEDA, Marina. «La casa de los Niños Expósitos de Écija (1602-1617)». En Luis Vélez de Guevara, IV Congreso de Historia de Écija. BOLAÑOS, P. y MARTÍN, M. (eds.), Sevilla: Excmo. Ayuntamiento y Fundación El Monte, 1996, pp. 365-378.

${ }^{56}$ El terremoto de Martinica, de...Representado por primera vez en el Teatro del Circo, el año de 1851. Prólogo mas cuatro actos. Madrid: Imprenta de Vicente de la Lama, 1859.

${ }^{57}$ Cita tomada del trabajo de RUBIO JIMÉNEZ, Jesús. «Melodrama y teatro político en el siglo XIX. El escenario como tribuna política». Castilla, vol. 14 (1989), pp. 129-149; p. 134. 
Y al igual que sucede en otras ciudades se representarán nuevas zarzuelas, generalmente de dos actos y con varios números musicales alternando con diálogos hablados. Uno de los autores más importantes fue Luis de Olona que estrenó, en 1856, El Postillón de la Rioja ${ }^{58}$, y, al año siguiente, Los Madgyares ${ }^{59}$. La primera no pasa de ser una obra de enredo en donde una Baronesa ha sido prometida por su tío, en matrimonio, a un Marqués, boda a la que llegará — dice la Baronesa- «siempre que el novio me parezca bien» ${ }^{60}$. En cambio, en Los Madgyares, calificada como 'zarzuela grande', presenta un tema histórico: María Teresa, reina de Hungría ha perdido la confianza del ejército y nobles de su país. Quieren obligarla a que abdique en favor del rey Federico II de Francia. Una primera revuelta popular no tuvo éxito y la tratarán de obligar, por segunda vez, pues de lo contrario matarán a su hijo. En esta ocasión el pueblo, ayudado por los comerciantes, salvará a la reina y al futuro rey. La acción se desarrolla en Hungría en el año de 1742. ¿A quién se le escapa el paralelismo evidente entre la situación política que se refleja en esta zarzuela con la vivida en España y su reina Isabel II?

Del mismo autor — Luis Olona- se estrenó en ¿1852? la comedia Maruja $^{61}$. Sin hacer una defensa encarnizada de los nobles, lo que sí plantea es la problemática de convivencia entre matrimonios desiguales, así como las ventajas de poseer una buena educación. También aparecen, claramente, alabanzas a la vida sencilla en las aldeas, como buen exponente del tópico sobradamente conocido. Dice Maruja, la mujer del Conde: «Yo he nacido en una aldea, he crecido en los campos y siempre me acordaré con alegría de aquellos tiempos» ${ }^{62}$.

La última obra seleccionada de esta década ha sido el drama Los pobres de Madrid (1857), de don Manuel Ortiz de Pinedo ${ }^{63}$. Su acción se sitúa en Barcelona y en Madrid, en el año de 1856. Este drama realista presenta la condena, fundamentalmente, del hombre avaro. Su protagonista, Mendilueta,

${ }^{58}$ El postillón de la Rioja, zarzuela original. En dos actos. Música del maestro Oudrid. Representada por primera vez en el teatro del Circo, el 7 de junio de 1856. Segunda edición. Madrid: Imprenta de M. Galiano, 1861. Está ambientada en el reinado de Felipe V.

${ }^{59}$ Los Madgyares, zarzuela en cuatro actos. Original de... Música del maestro don Joaquín Gaztambide. Representada por primera vez en el teatro de la Zarzuela en abril de 1857. Decoraciones pintadas por don Luis Muriel. Madrid: Imprenta de M. Galiano, 1860.

${ }^{60}$ El postillón de la Rioja, op. cit., p. 11.

${ }^{61}$ Maruja. Comedia en un acto. Escrita por... Representada con grande aplauso en el teatro del Circo (plaza del Rey) la noche del 4 de marzo de 1842, y posteriormente en los principales de España y Ultramar. Octava edición. Madrid: Imprenta de M. P. Montoya, 1889. El año de 1852, como fecha del estreno, lo ofrece el Catálogo de Autores dramáticos Andaluces, op. cit., p. 513, aceptándola como más correcta, dado que también existe una primera edición de ese mismo año.

${ }^{62}$ Ibidem, p. 12.

${ }^{63}$ Los pobres de Madrid. Drama en seis cuadros y un prólogo. Arreglado a la escena española por... Representado con extraordinario aplauso en el Teatro del Príncipe. Cuarta edición. Madrid: Imprenta de José Rodríguez, 1880. 
finge bancarrota y desaparece con todo el dinero de sus clientes, movido por la pasión de padre, de esta forma pretende hacer rico a su hijo. Uno de sus empleados, Trifón, hombre de pocos escrúpulos, quiere compartir el dinero de su jefe, pero en varias ocasiones sufrirá esquinazo. Estamos ante una de las pocas obras que en su totalidad nos presenta un problema social tan importante como fue la desigualdad abismal entre ricos y pobres. Luis, un pobre vergonzante, charla con un antiguo amigo - Andrés- que lo cree muy rico. $\mathrm{Y}$ en una de sus disertaciones presenta un amplio espectro de la pobreza que él bien conoce:

Más pobres se ocultan en Madrid bajo el vestido del elegante que bajo los harapos del jornalero: más miseria encubre el frac que la chaqueta (...). El pobre en Madrid es el empleado de poco sueldo y de mucha familia, que tiene que robar al apetito de sus hijos el gabán con que sale a la calle ó el napoleón que da de aguinaldo al portero de su oficina. ¡Pobre es el pintor de entusiasmo y de genio, que para no morirse de hambre en su desmantelada bohardilla, tiene que empeñar sus pinceles y sus paletas! ¡El hidalgo cuyo abolengo data de las Cruzadas, y que se abotona la levita hasta el cuello para que no se note su falta de camisa! El abogado sin pleitos y sin fortuna, y el médico sin enfermos. El actor sin ajuste, el poeta a quien no representan sus obras y el periodista sin importancia. Todas estas gentes andan vestidas, duermen bajo techado, y hasta comen alguna vez... ${ }^{64}$.

Toda la obra es un magnífico alegato para socorrer a los pobres vergonzantes pero planteado en plan irónico, pues se insta a que se dé lo 'superfluo', lo que nos sobra y no sabemos qué hacer con ello. No se habla de reparto, de justicia social. De aquí que Luis —el verdadero protagonista para nosotros- diga que no se hace justicia en la tierra, que era la única que podía salvar a los hombres - tal como defendió Fernando Salvatierra en La bode$g a$ - pero espera, que si alguna vez la hubiera, será implacable. Por ahora sólo confía en que se siga practicando la caridad ya que «Dios ha escrito en el libro santo de sus preceptos, como primera virtud, la Caridad» ${ }^{65}$. Estas son las últimas palabras de la obra. Como puede verse, un final nada revolucionario, en el que se apela a la resignación de las clases más desfavorecidas, lo que supone una auténtica bofetada para los sufridores de tantas injusticias y para los conocedores de la existencia de ladrones de guante blanco sobre los que no recae el peso de nuestra ley.

Termino el comentario de esta obra con la constatación de la existencia de centros de reclusión para los más necesitados. La denuncia pública de Rodríguez de Alba rápidamente hubo de ser recogida. A Trifón, en Los pobres de Madrid, lo encierran en San Bernardino, centro entre Psiquiátrico y Residencia; pero debió de ser una práctica generalizada también en los gobiernos locales disponer de este tipo de centros para asistir a la clase social más desprotegida, sobre todo con las leyes de beneficencia de 1849 y de sanidad,

\footnotetext{
${ }^{64}$ Ibidem, p. 18.

${ }^{65}$ Ibidem, p. 76.
} 
en 1855. En Écija también se cubrió esta necesidad con el Hospital de San Sebastián ${ }^{66}$, sin que pueda pensarse que fuera una panacea para cubrir tantas deficiencias como tenían.

A finales de la década de los sesenta, en los estertores del régimen isabelino y en los últimos años del gaditano José Sanz Pérez, se estrenó la pieza cómica Marinos en tierra ${ }^{67}$, antecedente claro del 'género chico' y del andalucismo teatral de los hermanos Álvarez Quintero. Juana, doncella en la casa de doña Consuelo, charla con Eduardo, gaditano y marinero, para saber qué aires respira:

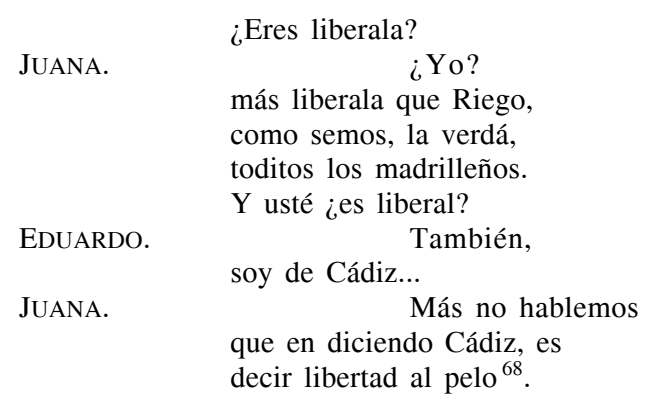

Como puede apreciarse, se identifica 'liberalismo' con el régimen político que concede más derechos al pueblo. Así lo concibe Eduardo:

Que la libertad es, niña,
puro rocío del cielo;
es sol divino que al hombre
le da sagrados derechos;
azote providencial
de los tiranos perversos ${ }^{69}$.

Cualquier otro posicionamiento político sería defender la tiranía para el pueblo. Por esa libertad dio su vida el padre de Juana, al que reconoce Eduardo como a un verdadero héroe:

\footnotetext{
${ }^{66}$ Cfr. el espléndido estudio de VALENZUELA CANDELARIO, José. Pobreza y asistencia benéfica. El hospital de San Sebastián de Écija, 1813-1942. Sevilla: Secretariado de Publicaciones de la Universidad de Sevilla, 1996.

${ }^{67}$ Marinos en tierra, pieza en un acto y en verso. Original de...Representada por primera vez con extraordinario aplauso en el Teatro de la Zarzuela, el día 3 de noviembre de 1868 . Quinta edición. Madrid, Establecimiento tipográfico de M. P. Montoya y Compañía, 1882. Este autor fue muy apreciado en toda la geografía española considerado como «uno de los máximos representantes del teatro llamado andaluz» (BOTREL, Jean-François. «El teatro en provincias...», art. cit.,p. 389. Cfr., también, el artículo de CANTOS CASENAVE, Marieta. «El teatro breve gaditano a mediados del siglo XIX..., art. cit.).

${ }^{68}$ Ibidem, p. 12.

${ }^{69}$ Ibidem.
} 


$$
\begin{aligned}
& \text { E ahí la imagen del pueblo; } \\
& \text { lágrimas vertiendo y sangre } \\
& \text { y dolores y tormentos, } \\
& \text { para darle a los malvados } \\
& \text { que en la rapiña vivieron, } \\
& \text { con su paciencia, la sombra, } \\
& \text { con su sangre, sacro riego }{ }^{70} \text {. }
\end{aligned}
$$

El enfrentamiento entre ricos y pobres se hace presente en esta obra en la persona del Barón cuando discute con Curro, otro marinero que acompaña al capitán Eduardo. Pero hay algo que puede igualar a los hombres: su entrega y valentía a la hora de la defensa de la Patria. Ésa ya la ha demostrado Curro.

La década de los setenta supuso - una vez planteada la Restauración de la dinastía Borbónica - una nueva fórmula de concebir la obra teatral. Hemos de hablar del período neorromántico o postromántico. Caminan paralelas dos vidas: la del rey Alfonso XII y la del escritor-dramaturgo Echegaray. Se produce una década tranquila políticamente hablando -aunque se está bajo la dictadura de Cánovas del Castillo, que cercena todas las conquistas sociales populares conseguidas en la etapa de 1868 a $1874-$ y a ese 'bienestar político' se le contrapone un tipo de teatro 'aterrador' al que el espectador acudirá para llorar con placidez.

A este período pertenecen los estrenos del juguete cómico Caiga el que caiga (1877) del gaditano Eduardo Sánchez de Castilla ${ }^{71}$, discípulo del gran maestro Sanz Pérez y al que siguió la pauta en su quehacer dramático-cómico; y la obra de otro paisano - Ildefonso Antonio Bermejo- titulada Sin comerlo ni beberlo (1879) ${ }^{72}$ que, a pesar de ser clasificada como 'comedia', en nada se diferencia —ni en extensión ni en intención- de la obra mencionada anteriormente ${ }^{73}$.

Respecto a la primera, poco hay que decir; el título da sentido a la misma y se encarna esta forma de pensar en el personaje Rufo, chupatintas e intrigante, sin escrúpulos sociales y dispuesto a pisotear los derechos del prójimo. Su filosofía de vida la deja plasmada en estas palabras que dirige al recto Federico: «Nada, si quiere Vd. medrar en este mundo, ríase Vd. de la moralidad, y caiga quien caiga» ${ }^{74}$. Como se aprecia, el ejemplo que toman los espectadores de las tablas no es demasiado aleccionador. También se constata

${ }^{70}$ Ibidem, p. 11.

${ }^{71}$ Caiga el que caiga, juguete cómico en un acto, por..., (firma autógrafa ). Madrid, 1877.

${ }^{72}$ Sin comerlo ni beberlo, comedia, en un acto y en prosa. Original de...Representada por primera vez con éxito extraordinario en el Teatro de Variedades, el 18 de abril de 1879. Segunda edición. Madrid: Imprenta de M.P. Montoya, 1887.

${ }^{73}$ Cfr. el artículo de GARCÍA LORENZO, Luciano. «La denominación de los géneros teatrales en España durante el siglo XIX y el primer tercio del siglo XX», en Segismundo, 3 (1967), pp. 191-199, donde podemos observar el amplio espectro de terminología utilizada por los autores para calificar su obra, sin que haya una razón profunda para tales distinciones.

${ }^{74}$ Caiga el que caiga, op. cit., p. 6. 
cómo «la enseñanza pública está muy desatendida en este país» ${ }^{75}$, pero, sin embargo, se han inaugurado una docena de plazas de toros en un mes. El disfrutar con el riesgo de que un hombre pueda perder la vida, parece atraer al público, masoquista y analfabeto, que, incluso, llega a protestar en la plaza si ese día no hay una cogida. La vida frívola de la falsa Marquesa - que se hace llamar así por haber amasado una fortuna siendo la amante de un Ministro- contrasta con la simpleza de Pepín, amigo del pueblo de la Marquesa, quien juzga con bastante rectitud a los políticos después de haber visto a su amiga como íntima de uno de ellos. A juicio de Pepín «es gobernador cualquier chichinabo» ${ }^{76}$. Su franco comportamiento haría reír a más de un espectador, pero al mismo tiempo también se identificaría con él por ser un excelente exponente de la verdadera situación del pueblo llano. «Éste, —diceno tiene nunca apetito lo que tiene, muchas veces es hambre». El final es edificante premiando al 'simple' y despidiendo la Marquesa a don Rufo, el intrigante, pero, a decir verdad, el castigo no está bien planteado pues cae un 'don nadie' quedando sin él el político de turno.

En la comedia Sin comerlo ni beberlo se pone en entredicho, una vez más, la honestidad de los políticos a los que si se les presiona pueden conceder prebendas.

En la década de los ochenta la vida política sufre un duro golpe con la muerte de Alfonso XII (1885). Ese binomio de la literatura y la política en manos de los oligarcas como si fueran una feliz pareja en plena luna de miel, empieza a resquebrajarse y a distanciarse la una de la otra. La finalidad de los literatos es presentar la dura realidad del pueblo español, es el realismo que Galdós empezará a cultivar y, desde este momento de concienciación, se empezará a practicar el llamado teatro social, teniendo que aguardar hasta la década siguiente para conocer sus mejores representaciones.

Galdós se rebela contra un teatro dominado, según él, por el 'ilusionismo' y la 'trivialidad'. Ilusionismo porque, la mayor parte de las piezas no presentaba hechos relacionados con la realidad española; trivialidad, en cuanto que nuestra realidad es muy compleja y el teatro estaba ausente de esta difícil situación: surgirá, de aquí, la llamada lucha de clases. Todos los temas intrascendentes van a quedar para ser tratados en lo que conocemos como 'genero chico' o 'teatro por horas', triunfando el sainete y la revista, especialmente.

Aunque es cierto que estas piezas breves no se centran exclusivamente en la crítica social, también se puede decir que aparecen breves alusiones en ellas que recogen esta problemática social que venimos investigando. Es posible que cuando se implante verdaderamente el teatro social, el género chico se reserve para otros hechos intranscendentes, como hemos dicho; pero para que eso suceda habrá que esperar hasta principios del siglo XX.

\footnotetext{
75 Ibidem, p. 9.

${ }^{76}$ Ibidem, p. 13.
} 
Y cultivando este género chico encontramos los más afamados dramaturgos del momento, todos ellos andaluces: el gaditano Javier de Burgos ${ }^{77}$, del que he seleccionado para su lectura el juguete cómico-lírico Caramelo $(1884)^{78}$, ¡Cómo está la sociedad! (1884) ${ }^{79}$, pasillo cómico-lírico, el sainete Los valientes $(1886)^{80}$, la zarzuela histórica Cádiz (1886) ${ }^{81}$ y El mundo comedia es (1889) ${ }^{82}$, sainete. El granadino Mariano Pina y Domínguez, con su revista, en un acto iEh...! ;A la plaza! (1880) ${ }^{83}$, La diva $(1885)^{84}$, zarzuela, no original sino que la arregló para la escena española de una obra de Offenbach y Madrid, Zaragoza y Alicante (1887) ${ }^{85}$, como juguete cómico. Estrenando otras obras en la década de los noventa, se han seleccionado para su lectura las comedias Matrimonio civil (1892) ${ }^{86}$ y González y González (1893) ${ }^{87}$. No menos mérito tuvo, el también gaditano, José Jackson Veyán que empezó a estrenar a finales de los ochenta, extendiendo su producción por la década de los noventa. Así, hemos leído el juguete cómico Chateau Margaux (1887) ${ }^{88}$,

${ }^{77}$ Cfr. LOZANO GUIRAO, Pilar. «Vida y obra de Javier de Burgos». Revista de Literatura, XXVIII, n. ${ }^{\circ}$ 55-56 (1965), pp. 39-64.

${ }^{78}$ Caramelo, juguete cómico-lírico en un acto, dividido en cinco cuadros, en verso. Original de... Música de los maestros don Federico Chueca y don Joaquín Valverde. Madrid, 1884.

${ }^{79}$ ¡Como está la sociedad!, pasillo cómico-lírico, en un acto y en verso. Original de... Música de los maestros Rubio y Espino. Madrid, 1884.

${ }^{80}$ Los valientes, sainete en un acto, dividido en dos cuadros, en verso. Original de... Estrenado con gran éxito en el Teatro Príncipe, el 14 de Agosto de 1886. Madrid: Establecimiento tipográfico de M.P. Montoya y Compañía, 1886.

${ }^{81}$ Cádiz, episodio nacional, cómico-lírico, dramático. En dos actos, dividido en nueve cuadros, en verso. Original de... Música de los maestros don Federico Chueca y don Joaquín Valverde. Madrid, 1887. Hace pocos años se ha hecho una edición por Alberto Romero Ferrer, citada anteriormente. Se estrenó el 20 de noviembre de 1886, en el Teatro Apolo de Madrid.

${ }^{82}$ El mundo comedia es o El baile de Luis Alonso, sainete en un acto, dividido en tres cuadros, en verso, original de... Madrid, 1890. Estrenada en el Teatro Español, el 12 de diciembre de 1889.

${ }^{83}$ ¡Eh...! ¡A la plaza! Revista en un acto, original de... Música de Don Ángel Rubio. Viene unida, como segundo acto Ellos y nosotros, cuadro cómico-lírico original de... y don Javier de Burgos. Música de don Ángel Rubio. Madrid, 1883.

${ }^{84}$ La diva, zarzuela, en un acto y dos cuadros, arreglada a la escena española por... Música de Ofembach (sic). Arreglada por el maestro Nieto. Madrid, 1885.

${ }^{85}$ Madrid-Zaragoza-Alicante, juguete cómico en un acto, basado en el pensamiento de una obra francesa por... Segunda edición. Madrid, 1887.

${ }^{86}$ Matrimonio civil, comedia en dos actos y en prosa, basada en el argumento de una obra francesa, por... Madrid: Eduardo Hidalgo, 1892.

${ }^{87}$ González y González, comedia, en dos actos y en prosa, basada en el argumento de otra francesa, por... Segunda edición. Madrid: Sociedad de Autores Españoles, 1899.

${ }^{88}$ Chateau Margaux, juguete cómico-lírico, en un acto y en verso. Letra de..., música del maestro Fernández Caballero. Representado con extraordinario éxito en el Teatro de Variedades el 5 de octubre de 1887. Madrid: Enrique Arregui, editor, 1887. 
Zaragoza $(1888)^{89}$ y ¡Al agua patos! $(1888)^{90}$, todas ellas pertenecientes al género chico, como a continuación comentaremos. Este mismo autor estrenó también obras en la década de los noventa, tales como: Los trabajadores $(1891)^{91}$ y las zarzuelas La indiana (1893) ${ }^{92}$ y Mari-Juana (1899) ${ }^{93}$, haciéndose eco del gusto de un público que seguía demandando la zarzuela (chica o grande), pues en este momento en nuestra cartelera goza de una actualidad como antes nunca había sucedido.

Para concluir con los autores de esta década de los ochenta, mencionar al sevillano Felipe Pérez y González, con una abundante producción dramática de diversos estilos, cultivando fundamentalmente la zarzuela y el género chico — como los autores mencionados anteriormente-. Se ha examinado, de entre las que se llevaron a escena en Écija, la zarzuela chica Lo pasado, pasado $(1889)^{94}$ y el apunte cómico-lírico Oro, plata, cobre y... nada $(1888)^{95}$. Ya en la década de los noventa le llevaron a las tablas La Restauración (1890) ${ }^{96}$, zarzuela ambientada en la Francia de 1816.

El último de los grandes - aunque suene a paradoja — del género chico fue el malagueño Guillermo Perrín y Vico. Obtuvo grandes éxitos con obras como La corte del Faraón, que aún se sigue representando. Los astigitanos pudieron presenciar, entre otras, el cuadro cómico-lírico Apuntes del natural (1888) ${ }^{97}$,

${ }^{89}$ ¡Zaragoza!, episodio lírico-dramático en un acto y tres cuadros, en verso, original de... Música del maestro Rubio. Estrenado en el Teatro Martín, por la compañía de Variedades, el 28 de abril de 1888. Madrid: Enrique Arregui, editor, 1888.

${ }^{90}$ iAl agua patos!, pasillo cómico-lírico-dramático, en un acto y dos cuadros. Original de... Música del maestro Ángel Rubio. Estrenado con gran éxito en el Teatro Felipe la noche del 25 de agosto de 1888. Madrid: Enrique Arregui, editor, 1888.

${ }^{91}$ Los trabajadores, pasillo cómico-lírico en un acto. Original y en verso. Libro de..., música del maestro Chapí. Segunda edición. Madrid: Arregui y Aruej, 1891.

${ }^{92} \mathrm{La}$ indiana, zarzuela en un acto y en verso. Libro de..., música de Arturo Saco del Valle. Representada con extraordinario éxito en el Teatro Eslava, el 21 de octubre de 1893. Madrid: Arregui y Aruej, editores. 1893.

${ }^{93}$ Mari-Juana, zarzuela en un acto y en verso. Música del maestro Joaquín Valverde (hijo). Representada con extraordinario éxito en el Teatro Romea la noche del 24 de febrero de 1899. Madrid: Arregui y Aruej, 1899.

${ }^{94}$ Lo pasado, pasado, zarzuela en un acto, escrita sobre el pensamiento de una obra francesa, por... Música del maestro Ángel Rubio. Representada por primera vez en el Teatro Martín de Madrid, en la noche del 20 de diciembre de 1888. Madrid: R. Velasco, 1889.

${ }^{95}$ Oro, plata, cobre y...nada. Apuntes para escribir una obra cómico-lírico-fantástica y casi trascendental, presentados en un acto y cuatro cuadros. Letra original de... Música del maestro Ángel Rubio. Representada por primera vez en el Teatro Martín de Madrid, en la noche del 20 de diciembre de 1888. Madrid: R. Velasco, 1889.

${ }^{96}$ La Restauración, anécdota francesa de 1816, arreglada en forma de zarzuela en un acto y en verso, por... Música de los maestros Rubio y Catalá. Representada por primera vez en el Teatro de Maravillas, el día 26 de julio de 1890. Madrid: R. Velasco, 1890.

${ }^{97}$ Apuntes del natural, cuadro cómico-lírico-pictórico, en un acto y cinco cuadros. Original y en verso de... y Miguel de Palacios. Música del maestro Ángel Rubio. Madrid: Florencio Fiscowich, 1888. 
la zarzuela chica ;Don dinero! (1887) ${ }^{98}$ y Certamen Nacional $(1888)^{99}$ que fue la obra que más éxito tuvo de toda la cartelera examinada, llegando a reponerse en estos diez años, siete veces.

A otro nivel de producción y fama estarían Francisco Macano, del que apenas se conocen sus datos biográficos (sólo sabemos que murió en Sevilla en 1891). Estuvo presente en la cartelera astigitana su zarzuela Torear por lo fino (1881) ${ }^{100}$ y el sevillano José Mota y González que, a pesar de su falta de instrucción, manejó con gran acierto la carpintería teatral de la época, produciendo un buen número de obras y del que hemos seleccionado su zarzuela Un capitán de lanceros (1882) ${ }^{101}$.

Todas y cada una de las obras mencionadas responden a las características propias del género, pero no todas ofrecen datos sobre la problemática que estamos examinando, razón por la que sólo se mencionarán los datos concretos que muestran la denuncia y/o avance social del pueblo español.

Las mujeres han recibido instrucción y ya saben leer y escribir. Pero no sólo la mujer de ciudad sino también la que vive en el pueblo. Mari-Juana, protagonista que da nombre a una obra de Jackson Veyán, e hija de Perico —alcalde de un pueblo castellano- está muy satisfecha por lo que ayuda a su padre.
PERICO.
¡Ea!, Ya escribió la chica
MARI. en media hora siete cartas. Llevo su correspondencia, municipal y privada ${ }^{102}$.

Esta conquista social del hecho de saber escribir el hombre y, sobre todo, la mujer, será irreversible y seguirá manifestándose en obras como las de los hermanos Álvarez Quintero, los cuales cierran el periodo que estamos estudiando. Por eso, Solita, protagonista de La reja cuando quiere verse con su novio ha de escribirle:

SOLITA.

...Hoy mismo (...) le he escrito cuatro letras...prometiéndole salir a la reja esta noche, a las diez, para que me diga todo eso que

\footnotetext{
98 ¡Don dinero!, zarzuela en un acto y cuatro cuadros, original y en verso de... y Miguel de Palacios. Música de los maestros Rubio y Espino. Madrid: Florencio Fiscowich, 1887.

${ }^{99}$ Certamen Nacional, proyecto cómico-lírico en un acto y cinco cuadros, original de... y Miguel de Palacios. Madrid: La novela teatral, Año VI, n. ${ }^{\circ} 218,1921$.

${ }^{100}$ Torear por lo fino, zarzuela en un acto. Original de... Música del maestro don Isidoro Hernández. Estrenada con gran éxito en el teatro Salón-Eslava, el 19 de mayo de 1881 y en el Jardín del Buen Retiro, el 2 de julio del mismo año. Madrid: Enrique Arregui, 1881.

${ }^{101}$ Un capitán de lanceros, zarzuela en un acto y en prosa, original de..., música del maestro Isidoro Hernández. Estrenada con buen éxito en el Jardín del Buen Retiro, de Madrid, la noche del 7 de agosto de 1882, segunda edición, Madrid: Imprenta de José Rodríguez, 1895 .

${ }^{102}$ Mari-Juana, de JACKSON VEYÁN, J., op. cit., p. 9. Incluso llega a ridiculizar MariJuana a su prima que vive en la ciudad porque pone «vida» $\mathrm{y}$ «halma».
} 
dice que tiene que decirme. Por cierto que como es tan ilustrado las he puesto con un temor...

ROSARIO. ¡Qué tontería!

SolitA. $\quad$ Es que me asaltan unas dudas ortográficas...Vamos a ver: tú ¡cómo escribes 'alicientes'?

Rosario. Mal, de seguro.

Solita. Yo lo he puesto con hache antes de la 'a' y de la 'i'. ¿Será eso una falta?

ROSARIO. Me da el corazón que es una sobra ${ }^{103}$.

Estas piezas breves se caracterizan por su ambientación contemporánea y gracias a ello descubrimos cómo todavía la gente más sencilla sigue estando cansada de los políticos que, en vez de gobernar, desgobiernan, y no le ofrecen soluciones a sus problemas sociales. Perico, hombre pueblerino y de nobles sentimientos, piensa que él sería capaz de gobernar y — dice-:

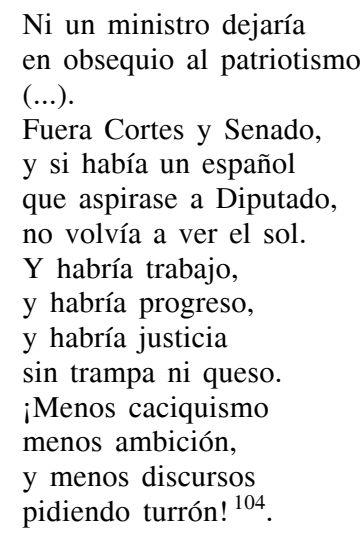

Otra de las grandes denuncias — aún no superada - es la desigualdad de salario entre el hombre y la mujer, realizando el mismo trabajo. Es posible que sea un mal endémico y no sea posible erradicarlo al ser consolidado desde el mismo momento que la mujer se incorpora al mundo laboral asalariado. El 'coro' de mujeres en Los trabajadores, de Jackson Veyán, canta, entre otras cosas, lo siguiente:

${ }^{103}$ ÁLVAREZ QUINTERO, Serafín y Joaquín. La reja, en Teatro completo. Madrid: 1923, t. I, p. 283.

${ }^{104}$ Mari-Juana, op. cit., p. 38. Al final de la obra, impreso también, aparece un apartado que dice «Letras para los complets de Perico». En ellas se critica duramente diversos aspectos de la realidad cotidiana. Cito, por poner un ejemplo, los siguientes versos: «Por las calles soltaría/ a la guardia veterana,/ y así no se atracaría por la noche y la mañana (...). Basta ya de timos/ basta ya de coba. Pan al que trabaja/ y palo al que roba,/ y menos intrigas / y menos charlar,/ y menos derechos / y más libertá. (Ibidem, p.[46]). 


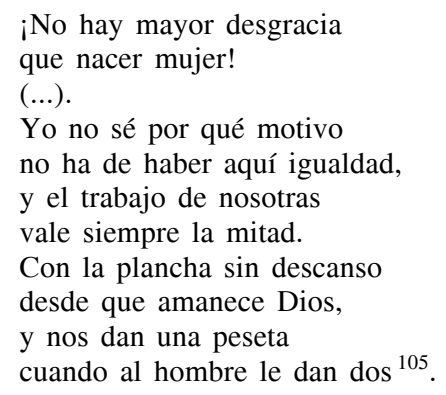

Como se puede comprobar, estas piezas encierran pequeñas críticas hacia los gobernantes, en general, pero también subyace una resignación, asumida por todos los trabajadores, que les hace ser dóciles pues —entienden- que no les es posible alterar su destino. Es muy posible que Fernando Salvatierra llevara razón cuando reconoce que «en vano se han intentado revoluciones en esta tierra. El alma de nuestras gentes es - dice- la misma que en tiempos de los señoríos. Guarda en lo más hondo la resignación del siervo» ${ }^{106}$. Y Jackson Veyan conoció bien a su gente. Y a sus trabajadores les dota, además de otras cualidades, de esa resignación amarga que les hace tirar para adelante, con demasiado escepticismo ante un futuro mejor. El coro de albañiles y carpinteros, en Los trabajadores, cantan:

$\begin{array}{ll} & \text { Entre yeso y ladrillos } \\ & \text { me paso el día, } \\ \text { y aunque hago tantas casas } \\ \text { ninguna es mía. } \\ \text { Subo al andamio, } \\ \text { y el hospital me espera } \\ \text { si es que me caigo. } \\ \text { Que le vamos a hacer. } \\ \text { A sufrir y aguantar. } \\ \text { El que quiera comer } \\ \text { tiene que trabajar }\end{array}$

Si ni la seguridad en el trabajo, ni el derecho a una vivienda digna son logros de nuestra época, cuanto menos de aquélla. ¿Qué es lo que pueden esperar de este valle de lágrimas? La caridad de sus congéneres. Dice Magdalena, una peluquera de Los trabajadores: «iSi no hubiera caridad /quien viviría en la tierra!» ${ }^{108}$.

Como vemos, en estas obras breves, no se refleja la angustia del pueblo llano demandando justicia social. Porque ese pueblo, representado en el per-

\footnotetext{
105 Los trabajadores, op. cit., p. 22.

${ }^{106}$ La bodega, op. cit., p. 386.

${ }^{107}$ Los trabajadores, op. cit., pp.10-11.

108 Ibidem, p. 13. Cfr. también, p. 17.
} 
sonaje de Simón — por ejemplo- jardinero del marqués de Montlusón, ( $\mathrm{La}$ Restauración) ve cómo han perdido conquistas sociales de otras épocas, caminando hacia atrás en la actualidad. Se sitúa la trama de esta obra en 1816, en la restauración francesa, pero bien se puede leer entre líneas el paralelismo de un país y una época determinada, con la situación española actual. Habla con Constanza, una de las hijas del Marqués. Dice Simón:

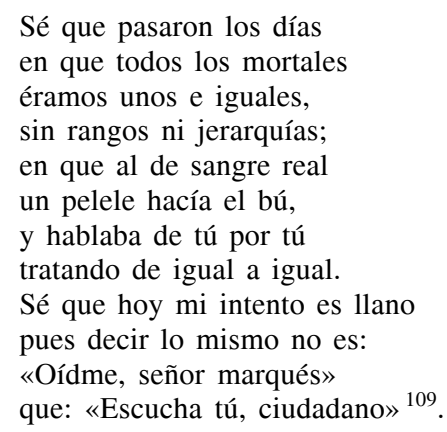

Pero si el pueblo llano aspira a subir en la escala social y no lo consigue, al menos, la nobleza parece haberse dado cuenta que corren otros tiempos y tiene que adaptarse a ellos. Nuestro 'marqués' nos sorprende por su modernidad al decir:

\author{
No son las ideas rancias \\ de nuestros antepasados \\ ni las revolucionarias. \\ No abomino la nobleza \\ ¿yo, cómo la he de abominar? \\ Pero no desprecio al pueblo \\ que es honrado y que trabaja, \\ ni el plebeyo que se encumbra \\ por sus méritos, me agravia. \\ Yo soy hombre de mi siglo \\ y marcho según él marcha. \\ ¿Qué? ¿Los treinta últimos años \\ no iban a servir de nada? \\ ¿No iban a enseñar, al menos, \\ y ya es útil la enseñanza... \\ que el talento, el heroísmo \\ y otras cualidades altas, \\ valen más, seguramente, \\ que las frívolas ventajas \\ del nacimiento? ${ }^{110}$.
}

\footnotetext{
${ }^{109}$ La Restauración, op. cit., p. 14.

${ }^{110}$ La Restauración, op. cit., pp. 25-26.
} 
Tal vez podría referirse a los treinta últimos años desde la Restauración del '68, pues, a pesar de no haberse conseguido una instauración plena de los derechos de los trabajadores, sí, al menos, han supuesto un claro avance respecto a lo que había antes.

Termina Felipe Pérez y González la obra de Los trabajadores con estas frases en pro de un gobierno de izquierdas:

$\begin{array}{ll}\text { SimóN. } & \text { La Restauración podrá } \\ & \text { volver costumbres añejas, } \\ \text { pero las ideas viejas } & \\ \text { murieron por siempre ya... } & \text { Habrá otra vez faustos regios, } \\ & \text { cortesanos esplendores, } \\ \text { mas no siervos ni señores, } \\ \text { ni castas ni privilegios. } \\ \text { Ya el mérito es quien da el nombre, } \\ \text { que por algo ha sido escrita } \\ \text { la declaración bendita } \\ \text { de los derechos del hombre... } \\ \text { Nunca la Restauración } \\ \text { su recuerdo borrará } \\ \text { pues siempre el mundo dirá: } \\ \text { ¡Gloria a la Revolución! }{ }^{111} .\end{array}$

Todo ello es un claro alegato en defensa de la primera República que, en una Carta Magna o Constitución, por primera vez, dejó plasmados los derechos de todas las personas.

Para completar el amplio abanico de autores y obras estudiadas debo concluir mencionando cuatro nuevos nombres que, en los últimos años de la década de los ' 90 crearon sus obras e inmediatamente fueron llevadas a las tablas astigitanas. Así sucedió con el jienense Diego Jiménez Prieto y su obra El pillo de la playa $(1898)^{112}$; con el sevillano Clemente García de Castro y Río que trabajó en colaboración con el gaditano Manuel Grosso Romero la zarzuela Los acróbatas (1895) ${ }^{113}$. Y de Cádiz fue Carlos Fernández Shaw, que llevó a las tablas del teatro de Écija el sainete La revoltosa $(1897)^{114}$ y la zarzuela La chavala (1898) ${ }^{115}$. Cierran el elenco los hermanos Álvarez Quin-

${ }^{111}$ Ibidem, op. cit. p. 46.

112 JIMÉNEZ-PRIETO, Diego y MONTESINOS, Eduardo. El pillo de la playa, zarzuela, en un acto y en verso. Original de... Música de los maestros Hermoso y Chalons. Estrenada en el Teatro Romea la noche del 10 de noviembre de 1898. Madrid: R. Velasco, 1898.

${ }^{113}$ GARCÍA, Clemente y GROSSO, Manuel. Los acróbatas, zarzuela cómica en un acto y dos cuadros. Letra de los señores... Música original de don Salvador Viniegra.

${ }^{114}$ FERNÁNDEZ SHAW, Carlos. La revoltosa, argumento del sainete en un acto y tres cuadros, en verso. Música del maestro R. Chapí. Estrenado en Madrid, en el teatro de Apolo el 25 de noviembre de 1897. Madrid: Galería de Argumentos, 1901.

${ }^{115}$ LÓPEZ SILVA, José y FERNÁNDEZ SHAW, Carlos. La chavala, zarzuela en un acto, dividido en siete cuadros. Original de... Música del maestro Ruperto Chapí. Estrenada 
tero, representándose en tierras astigitanas tres de sus primeras obras: La reja, comedia en un acto; La buena sombra, sainete en tres cuadros; y Los borrachos (1899) ${ }^{116}$, otro sainete en cuatro cuadros.

Hemos dejado para nuestro comentario postrero — dentro de la década de los '90 - la obra Certamen Nacional, de Guillermo Perrín y Vico. Fue, sin duda, la obra que mayor éxito logró pues, prácticamente, no desapareció anualmente de la cartelera teatral. Este 'proyecto cómico-lírico' en un acto, dividido en cinco cuadros ( $\mathrm{y}$, por lo tanto, género chico), podría decirse que es el prototipo de obra que se vino representando por estos años. Es cierto que no alude a todas y cuantas conquistas sociales había obtenido el pueblo, pero sí deja enunciados las que aún no se han conseguido: la igualdad social, que las revueltas sirvan para mejorar algo, que no existan ambiciones políticas sólo para enriquecerse, la falta de trabajo...Todo esto se escucha de boca de Patricio que, según su esposa está loco y, como los borrachos y los niños, siempre dice la verdad. Ante el profesor 'aljenista' que ha de curarlo, lanza estas preguntas retóricas:

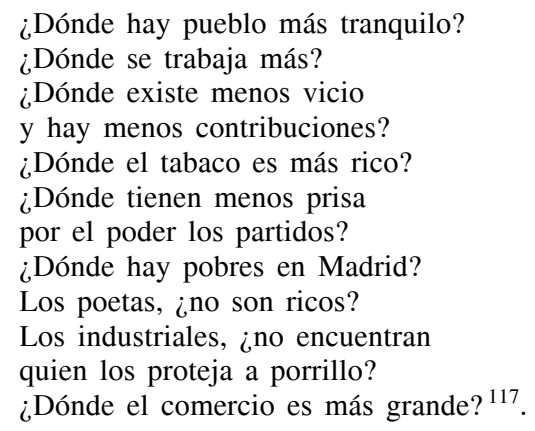

El Pata, personaje popular madrileño, no aprecia demasiado a la aristocracia y dice:

Aquí está la aristocracia

la que vive y lo que hace,

vamos, la que no hace nada ${ }^{118}$

Y siempre ha de ser el mismo el que sea capaz de sacar los grandes problemas adelante: el pueblo trabajador.

en el teatro de Apolo la noche del 28 de octubre de 1898. Cuarta edición. Madrid: R. Velasco, 1901.

116 ÁLVAREZ QUINTERO, Serafín y Joaquín. Teatro Completo. Madrid, 1923, t. I. La reja, pp. 269-311; IV: La buena sombra, pp. 5-64; y Los borrachos, pp. 65-134.

${ }_{117}$ Certamen Nacional, cuadro I (s.p.). Se desarrolla este cuadro en Madrid.

${ }^{118}$ Ibidem, cuadro II (s.p.). 
Agustina. Madrid vale y toos valemos y solo con el trabajo logran los pueblos a ser grandes ${ }^{119}$.

Pero la incultura general estará al orden del día mientras que 'la baraja' (juego de naipes) sea el libro más leído por el pueblo español ${ }^{120}$. Aún siendo un juego popular y aludiendo a él metafóricamente, también es el pueblo el más perjudicado cuando lo practica. Se dice:

$\begin{array}{ll} & \text {...Pero el pueblo es el peor, } \\ \text { porque no sabe jugar. } & \text { Hace siempre un mal papel } \\ & \text { con el gobierno jugando; } \\ \text { juega al burro, pues andando, } & \text { el burro se queda él. } \\ & \text { Si es a los cuernos, ya baja; } \\ & \text { son sus destinos amargos. } \\ & \text { Contribuciones, recargos, } \\ & \text { se queda con la baraja. } \\ & \text { Siempre le impone la ley } \\ & \text { al monte, y el pueblo, nada, } \\ & \text { jugando a la descargada... } \\ & \text { iCataplón! En puerta jel rey! } \\ & \text { Hasta que un día revienta } \\ & \text { y el pueblo ya no discute, } \\ & \text { se pone a jugar al tute } \\ & \text { y le acusa las cuarenta. } \\ \text { Siempre lo mismo ha pasado. } \\ \text { PATRICIA. } & \text { Pues paciencia. } \\ \text { PROFESOR. } & \text { Y barajar }{ }^{121} \text {. } \\ \text { BARTOLO. } & \end{array}$

Estos personajes tipos, utilizando un lenguaje metafórico, configuran una obra con la que podrían reírse unos cuantos, pero para el pueblo en general no era más que la dura realidad que tenía que seguir soportando, al mismo tiempo que no dejó de soñar:

Este puchero de miel se paece mucho a esta tierra; el pueblo trabaja mucho, lo mismo que las abejas,

\footnotetext{
${ }^{119}$ Ibidem.

${ }^{120}$ En el teatro del Siglo de Oro ya se alude a las 'cartas' como el 'libro real', pues tenían que tener licencia de su Majestad para ser impresas (Cfr. La cárcel de Sevilla, entremés, atribuido a Chaves y/o Miguel de Cervantes. Dice Coplilla: «¿Qué manda voacé?», a lo que contesta Barragán: «Daca el libro real, impreso con licencia de su Majestad». AA.VV. Cuaderno de teatro andaluz del siglo XVI, REYES, Mercedes de los, BOLAÑOS, Piedad y otros... (eds.), Sevilla: Consejería de Cultura, Centro Andaluz de Teatro/Centro de Documentación de las Artes Escénicas de Andalucía, 2004.

${ }^{121}$ Certamen Nacional, cuadro III, (s.p.).
} 


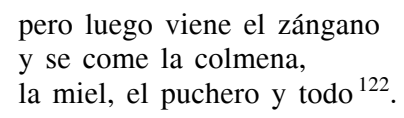

Se concluye toda la ácida crítica vertida en esta magnífica obra con unas palabras del profesor, ese hombre que estaba obligado a curar las locuras de sus pacientes. Él tiene una 'receta' excelente para quien quiera practicarla, pero creo - humildemente- que ni en aquellos tiempos ni en éstos, se está en condiciones de practicarla:

$$
\begin{aligned}
& \text { Lo que nos precisa } \\
& \text { es que le den protección } \\
& \text { al pueblo que suda tinta } \\
& \text { trabajando sin descanso, } \\
& \text { sin ver premio a sus fatigas. } \\
& \text { ¿Sabe Vd. cuándo nosotros } \\
& \text { haremos cosas magníficas? } \\
& \text { Cuando vengan Municipios, } \\
& \text { que no vendrán en la vida, } \\
& \text { que administren para el pueblo } \\
& \text { de una manera más cívica. } \\
& \text { Cuando aquí no se discuta, } \\
& \text { cuando cesen las envidias, } \\
& \text { cuando haya administración } \\
& \text { y algo menos de política } \\
& \text { y se dé al César lo suyo } \\
& \text { y al pueblo lo que le quitan }{ }^{123} \text {. }
\end{aligned}
$$

Cuando ese día llegue, habrá justicia social.

\section{COMPARACIÓN CON OTRAS CIUDADES ESPAÑOLAS}

No es posible terminar el examen de esta cartelera teatral y por ende hacer una valoración sobre qué mensaje recibió el pueblo astigitano que la presenció, sin contrastarla con lo que pudieron ver otros pueblos españoles en otras ciudades de nuestro gran territorio nacional. ¿Asistieron a obras de muy diversa naturaleza a las nuestras? ¿Los autores andaluces fueron los preferidos por los empresarios de esas otras tierras, a sabiendas que sus obras iban a ser mejor aceptadas y más aplaudidas? No parece probable que el 'capital' entienda de geografía, al igual que siempre ha distinguido entre clases sociales. Allá donde hubiera ganancias, aquello era bueno. Fiel reflejo de lo que argumento es un hecho que ocurrió en la propia Écija. Llegó Rafael Ferrera y Sánchez «...como representante del Teatro Principal de Écija en la próxima feria de esta Población», el cual, estando la temporada teatral en ciernes por-

\footnotetext{
122 Ibidem.

${ }^{123}$ Certamen Nacional, cuadro IV (s.p.).
} 
que se aproximaba la feria, se dirige al Cabildo Municipal en los siguientes términos:

«...accediendo a los deseos de multitud de vecinos de Écija, ha entrado en negociaciones con el Señor Giovannini, Director de la Gran Compañía de Ópera y Ópera cómica Italiana que ha venido actuando hasta hace poco en el Teatro Eslava de Sevilla, con el fin de que trabaje en este teatro durante la feria de septiembre y días anteriores y posteriores» ${ }^{124}$.

$\mathrm{Su}$ objetivo es solicitar una ayuda de 500 pesetas para hacer frente a los gastos «extraordinarios sobre los que aquí son corrientes en esa clase de espectáculos». Lleva fecha el documento del 17 de agosto de $1895^{125}$. La comisión de Ferias y Fiestas informa favorablemente la petición del Sr. Ferrera, apoyándose en que «ese vecindario tiene demostrada su afición a recreos y festejos cultos...», lo que nos puede ayudar a ratificar nuestra hipótesis sobre que:

1) El público asistente debió de ser de clase media-alta;

2) que la cartelera de esta compañía era poco sospechosa de llevar en su repertorio ninguna ópera cómica con reivindicaciones sociales del pueblo andaluz;

3) que los empresarios contrataban a las compañías que estuvieran más cercanas a su ciudad, dado que hoy como ayer, y ayer como en los Siglos de Oro, siempre ha habido unas rutas preestablecidas que se seguían año tras año ${ }^{126}$.

Por esta razón y fijándonos en primer lugar en la actividad escénica de León ${ }^{127}$, sabemos que el público que acudía al teatro también era la burguesía ${ }^{128}$, como, por regla general, en todos los lugares de España — pues era la

${ }^{124}$ ARCHIVO MUNICIPAL DE ÉCIJA, Legajo 291, doc. 63, fol. $1 \mathrm{r}^{\circ}$.

${ }^{125}$ No conocemos la cartelera teatral de este empresario ni de este año, por no haberse conservado en el Archivo Municipal de Écija el listado correspondiente. Lo mismo ocurre con el año de 1894.

${ }^{126}$ Pero ello no quiere decir que, antes o después, una misma compañía no pudiera recorrer toda España. Como ejemplo les pongo el caso de la compañía de Mariano Guillén, especializada en zarzuela 'chica', que está en Écija, por primera vez, desde octubre a diciembre de 1891. En Ávila, ésta misma, trabaja en junio y julio de 1899. Llenó el teatro, pero fracasó en su intento por implantar el 'teatro por horas'.

${ }^{127}$ FERNÁNDEZ GARCÍA, Pablo. León y su actividad escénica en la segunda mitad del siglo XIX. Madrid: UNED, 1997.

${ }^{128} \mathrm{~A}$ cualquiera de los estudios que nos acerquemos comprobamos que, con unas u otras palabras, todos los críticos han aceptado que el teatro del XIX es fruto de un público burgués. Dice María del Pilar FERNÁNDEZ, respecto al teatro Canario de esa época: «Es, por lo tanto, un teatro vivo, muy apegado a los intereses y divertimento de la burguesía que los demanda y de la gestión de esta clase a través de los Ayuntamientos y sociedades culturales» (Cfr. «Compañías y obras: notas para una aproximación al teatro canario del siglo XIX» en Historia y crítica del teatro de comedias del siglo XIX...... Y la burguesía también se divierte, El Puerto de Sta. María, Fundación Pedro Muñoz Seca, 1995, pp. 282-287; p. 286). 
que detentaba el poder - y «la obra corta acabó prevaleciendo sobre la de larga duración y las producciones cómicas se preferían al teatro serio», según ha dejado por escrito Fernández García ${ }^{129}$.

De un total de 770 obras representadas en la época estudiada, 243 son musicales y 455 tienen un solo acto. Haciendo una cala en la cartelera representada en Écija y eligiendo para ello la década de los 80 , podemos decir que de las 18 obras de autores andaluces que nosotros conocemos, ellos no llevan a sus escenarios, 7 , siendo Felipe Pérez el autor más castigado, dado que su producción es totalmente desconocida en aquella cartelera. No sale muy bien parado el autor de Certamen Nacional -Perrín y Vico- aunque esta obra, en concreto, fue repuesta en cuatro ocasiones, siendo lo normal que no pasaran de dos.

De Ávila, ciudad muy semejante por el número de habitantes a nuestra Écija, también se ha realizado el estudio sobre esta época teatral ${ }^{130}$. En esta ocasión confrontaré todas las obras anotadas como representadas en Écija en el año de 1898 — año crucial para la historia de España. En más de una ocasión se refleja en nuestras obras la problemática Guerra de la Independencia de Cuba - y las representadas en aquella ciudad ${ }^{131}$. En Écija se llevaron a las tablas 49 títulos diferentes y la mayoría de esas obras se repusieron en varias ocasiones. De ellas, sólo 13 coinciden con la cartelera de Ávila de aquellos años; y, solamente, de una de ellas es andaluz su autor (Pina Domínguez, y su obra (González y González). No creo que podamos decir que la cartelera astigitana sea 'casera' pues aparecen en la de Ávila varios autores andaluces que fueron reconocidos a nivel nacional (Marian Pina; José Mota González; los hermanos Quintero y Javier de Burgos, siendo el primero de los mencionados el que más piezas llevó a los escenarios abulenses). Hemos de resaltar que, al menos, la obra social por excelencia —Juan José (1895)— de Joaquín Dicenta, se encuentra presente en ambas carteleras. De este mismo autor y escrita un año después es la obra El señor feudal (1896), pieza muy semejante -en cuanto a la crítica social - a la revolucionaria Juan José y que no fue bien aceptada por el público. Puesto que no poseemos la crítica de ésta, recogemos lo que se dice de la segunda:

«El drama de Dicenta ha sido ya, en otras ocasiones, representado en nuestro teatro, y nada hemos de decir por tanto, de su significación y tendencias francamente socialistas. Muchas son las iniquidades sociales que a diario tenemos que lamentar, y no es la menor culpa de que aquellas se cometan la que corres-

\footnotetext{
${ }^{129}$ FERNÁNDEZ GARCÍA, Pablo. León y su actividad escénica en la segunda mitad del siglo XIX, op. cit., p. 347.

${ }^{130}$ Cfr. QUIRÓS MATEO, José Antonio Bernardo de. Teatro y actividades afines en Ávila (siglo XVII, XVIII y XIX). Madrid: UNED, Tesis Doctoral, 1993/94.

${ }^{131}$ Tenemos un pequeño inconveniente: en la cartelera de Ávila se han conservado conjuntamente los años de 1898 hasta 1900, por lo que no podemos saber exactamente — de todas las obras que se representan- cuáles lo hacen en un año y cuáles en otro.
} 
ponde a los autores que, mirando más que el éxito de sus obras, no reparan en difundir ideas y enseñanzas perniciosas de las que el público se apodera con avidez malsana y que a la corta o a la larga llegan a producir siempre sus naturales resultados» ${ }^{132}$.

La prensa astigitana no se hizo eco de ninguno de los estrenos de Dicenta por estos años.

Tampoco se refleja en ninguna de las dos carteleras que estamos comparando obra alguna de Benito Pérez Galdós, claro precedente del teatro social revolucionario (Realidad, 1892; La loca de la casa, 1893; Gerona, 1893; La de San Quintín, 1894; Los condenados, 1894; y Voluntad, 1895). Pero, sin embargo, Galdós sí que es conocido y representado en su patria chica, Las Palmas de Gran Canaria, en donde llevó a las tablas La loca de la casa y consiguió que la crítica le fuera favorable. Excusan los críticos la presencia en el escenario de buenos autores por las exigencias del público que «desdeña y pospone — dicen - el arte serio a la explotación indigna del llamado género chico» ${ }^{133}$. Con este dato quiero poner en evidencia que siempre es más frecuente que se representen obras de los paisanos en su propia tierra, pues el vínculo personal de los empresarios y las presiones de los amigos pueden ayudar a subir esa obra a un escenario —en principio- local.

Concluyo este breve acercamiento a otras carteleras teatrales viendo, en esta ocasión, cuántas obras se representaron en Albacete durante la segunda mitad del siglo XIX (como reza el título del trabajo) de ciertos autores andaluces — por poner algunos ejemplos - y cuántas, de esos mismos autores, se representaron en Écija en los diez años que nosotros estamos comentando. A Javier de Burgos le representan 7; en Écija, 9, coincidiendo todos los títulos de la capital manchega más La boronda y La mujer del molinero. Mariano Pina Domínguez está presente con 22 obras en Albacete; en Écija se dan 21 piezas distintas. De ellas coinciden 8 títulos y el resto son obras diferentes ${ }^{134}$. De José Jackson Veyán, se representan 14 obras en Albacete y 20 en Écija. Coinciden 8 títulos y el resto varía de una a otra ciudad ${ }^{135}$.

Este estudio comparativo nos lleva a ratificar lo que hasta el momento habíamos intuido: la presencia de los autores andaluces en todas las ciudades españolas, aunque en Écija es siempre superior por tratarse de ese espacio geográfico 'casero' en donde es probable que se estrenaran —incluso- obras para ver cómo las acogía su público.

132 Ibiden, p. 640.

${ }^{133}$ LÓPEZ CABRERA, María del Mar. El teatro en Las Palmas de Gran Canaria (18531900). Madrid: UNED, Curso Académico 1994/95, p. 957. Tesis doctoral publicada por la FUE, 2003.

${ }^{134}$ Cfr CORTÉS IBÁÑEZ, Emilia. El teatro en Albacete en la segunda mitad del siglo XIX. Madrid: UNED, 1991, p. 421. Editado en 1999. Para las obras de la cartelera astigitana, remito a los cuadros correspondientes para su comprobación.

135 Ibidem, pp. 410-411. 


\section{V. ¿REBELDÍA SOCIAL EN LAS TABLAS? CONCLUSIONES}

Debemos tener muy claro, antes de plantear cualquier tipo de valoración de la cartelera teatral examinada, que, como hemos podido comprobar, las obras representadas en esa década de finales del siglo XIX fueron escritas, en algunas ocasiones, bastantes años antes, es decir, que el público astigitano asistió a demasiadas 'reposiciones'. Por esta razón presenciaron obras creadas en muy distintos períodos correspondientes a diversas épocas políticas de todo el siglo XIX. Como sostiene Jesús Rubio:

«dada la progresiva estrechez de miras del estado liberal asentado tras la muerte de Fernando VII (...) las limitaciones de la libertad de expresión fueron creciendo de tal manera que con frecuencia hicieron imposible el debate político encarnado en personajes dramáticos». La censura fue férrea y «cercenó - sigue diciendo Rubio- implacable cualquier intento de teatro verdaderamente crítico de aquella sociedad cada vez más moderada y mediocre hasta su autoliquidación en la Revolución de $1868{ }^{136}$.

Juicios que fueron corroborados por la actitud de los diversos gobiernos a lo largo de ese siglo puesto que, cuando debieron regular las

«normas o leyes sobre imprenta, que eran las que en definitiva regulaban la libertad de expresión (...) ni se menciona al teatro» ${ }^{137}$.

Esto prueba que los

«Gobernantes y legisladores del S. XIX no consideraban al teatro como un instrumento de exposición de ideas y de libertad de expresión, sino como de mero entretenimiento» ${ }^{138}$.

Para reconocer y poder hablar de un verdadero teatro social en el siglo XIX, hemos de esperar la llegada de Galdós, como se ha comentado, para ver plasmados en el teatro problemas de 'ideas', sustituyendo los 'conflictos de pasiones'. Subieron entonces a las tablas

«personajes de las clases más desfavorecidas, ahora tratados con toda seriedad —dice Antonio Fernández- evitando el tono habitualmente jocoso de la literatura sainetesca, haciendo hincapié en la explotación económica a que se encuentran sometidos» ${ }^{139}$.

${ }^{136}$ RUBIO JIMÉNEZ, Jesús. «José María Gutiérrez de Alba: creador de la revista teatral política». En: Literatura y Política en el Siglo XIX,... op. cit., pp. 83-101; p. 83.

${ }_{137}^{137}$ Se dieron leyes sobre la imprenta en $1830,1857,1864,1865,1866,1867,1868,1875$, 1879 y 1883. (Cfr. PASCUAL MARTÍNEZ, Pedro. «Parlamento y teatro en el siglo XIX». En: Historia y crítica del teatro de comedias del siglo XIX..., op. cit., pp. 324-334; p. 330. ${ }^{138}$ Ibidem.

${ }^{139}$ FERNÁNDEZ INSUELA, Antonio. «Galdós y el drama social», art. cit., p. 2012. 
Pero si en los primeros años del siglo XIX la censura fue férrea, ahora, a finales del mismo siglo, el autor teatral que quiera difundir sus ideas proselitistas y llegar al mayor número de espectadores, ha de enfrentarse con los espectadores más reaccionarios, tanto con la crítica periodística, como con los empresarios, teniendo que llegar a un tácito pacto que le permita representar su texto dramático en locales típicamente burgueses. Nadie mejor que estos burgueses para aplaudir el 'género chico' pues ellos se consideraban 'superiores' a los personajes allí retratados y les reían sus gracias. Son hombres y mujeres conservadores que tacharon a los autores de teatro como de escritores 'extraviados', esclavos de aquella copla que dice: «Si un pueblo es inmoral, nada más justo/ que inmoral ser con él, por darle gusto». Juicio que hace buena la opinión de Mariano Arenilla Sainz que, en El Diario de Ávila escribió un artículo demoledor contra el teatro de finales del siglo XIX, del que entresaco estas líneas:

«Hoy las relaciones entre los escritores y el público se han convertido en relaciones mercantiles, y aquellos, en vez de tener delante la preceptiva literaria, fijan su mente en la taquilla o en la venta trimestral que les producen sus esperpentos literarios» ${ }^{140}$.

Establecidas estas premisas, estamos en condiciones de enumerar las características más destacadas de la cartelera astigitana de la última década del siglo XIX:

1) Hay 'reposiciones' de obras estrenadas con bastantes años de antelación. A medida que avanzamos en el tiempo dentro de la década, la nota predominante es la representación de una obra muy cercana a la fecha del estreno, lo que nos hace pensar que Écija era una buena plaza para los empresarios.

2) Por la selección de autores andaluces impuesta desde el principio, predomina la zarzuela ${ }^{141}$ (fundamentalmente 'chica') y el 'género chico' (con todo su abanico de variantes), por ser los 'amos' de estos géne$\operatorname{ros}^{142}$. Ninguna obra está dedicada en su totalidad a la crítica social pero sí aparecen 'pinceladas' breves, donde se refleja alguna preocu-

${ }^{140}$ Cita tomada de BERNALDO DE QUIRÓS MATEO, José Antonio. Teatro y actividades afines en Ávila..., op. cit., p. 833.

${ }^{141}$ Emilia Cortés llega a decirnos que «la zarzuela en 3 actos, tiene un período de esplendor en los años ' 60 , decae algunos años, para volver a renacer con fuerza en los ' 90 , con un acto, convirtiéndose en el género más frecuente en el período de 1896-1900» (Cfr. CORTÉS IBÁÑNEZ, Emilia. El teatro en Albacete en la segunda mitad del siglo XIX..., op. cit., p. 385).

${ }^{142}$ Constatamos esta aseveración con palabras pertenecientes al estudio del teatro en Albacete que nos dice su autor: «La mayoría de los autores que recogemos en nuestro trabajo, por ser su producción frecuente en la escena de Albacete, son andaluces...», op. cit., p. 390. 
pación por estos temas sociales. Confirman mis palabras iniciales en las que insinuaba estar ante una 'cartelera' de teatro - por la selección o criterio aplicado para su examen- de corte popular (tanto si se representaba la 'zarzuela chica' o el 'teatro por horas', con o sin música) que siguió la línea costumbrista, de intencionalidad cómica no exenta de cierta crítica satírica.

3) Se apuntan problemas sociales totalmente novedosos, que no fueron ni siquiera cuestionados desde la teoría política social y que aún hoy día están por resolver. Por ejemplo, la diferencia de salario que la mujer cobra frente al hombre, realizando el mismo trabajo.

4) Hubo autores andaluces que se subieron al carro del teatro social, revolucionario o teatro moderno, como pudo ser el gaditano Federico Oliver que estrenó La muralla en 1898 y, algunos años más tarde, el sevillano López Pinillos; ni la producción del uno ni la del otro se hace presente en el periodo estudiado. La denuncia social la hemos de buscar en la novela de finales de siglo. Para que haga lo mismo el teatro hemos de esperar a los primeros años del siglo XX. Nosotros hemos examinado un teatro contemporáneo, no moderno, que se relaciona con el teatro popular del siglo XIX, como señala Torrente Ballester ${ }^{143}$.

5) Hemos hablado, líneas más arriba, de 'tácito' pacto entre los autores y los empresarios para eliminar de las obras todo lo que pudiera molestar al público burgués. Pues bien, no fue solamente tácito sino que autores como Felipe Pérez y González dejó impreso que «todos los versos que van señalados con * (ASTERISCO) pueden ser suprimidos en la representación» ${ }^{144}$. ¿A qué versos se refiere el autor? A todos los que hemos citado en este trabajo - y algunos más...-, pues podría ser tachado su autor de revolucionario y molestar a más de un espectador reaccionario.

6) Por regla general, los textos examinados enuncian o denuncian situaciones de abuso del poder, pero no proponen revoluciones para erradicarlas. Son textos, en su mayoría, conformistas como en parte lo fue La bodega pues la desilusión — tras el fracaso- embargó al protagonista y hubo de emigrar a tierras Americanas.

El crítico José Ixart, en 1894, ya escribió sobre la facilidad que el andaluz tenía para componer de forma festiva:

«Las provincias andaluzas dan por sí solas un contingente mayor de poetas festivos y ligeros, casi improvisadores, que muchas otras regiones de España juntas» 145 .

${ }^{143}$ TORRENTE BALLESTER, Gonzalo. Teatro Español Contemporáneo. Madrid: Guadarrama, 1957, pp. 17-25.

${ }^{144}$ La Restauración, op. cit., p. 9.

${ }^{145}$ Cita tomada de CORTÉS, Emilia (est.). El teatro en Albacete..., op. cit., p. 390. 
De 'parcial' podrán tacharme por haber seleccionado sólo a los autores andaluces para mi estudio. No por ello hemos dejado de cumplir con nuestra misión aunque reconozco que no fueron los autores más preocupados por las penurias que su pueblo estaba padeciendo. Termino este ensayo sobre la cartelera astigitana reconociendo que estamos ante una gran ciudad y un excelente público que aunque fuera para 'pasar el rato' — como dice Jacinto Octavio Picón en su Prólogo a El año teatral- acude al festejo cómico ratificando la vocación que desde 1619 había demostrado al solicitar que se hiciera un corral de comedias y que se mantendrá — con sus rehabilitaciones sucesivashasta 1936, año en que sufrió un devastador incendio.

\section{REFERENCIAS BIBLIOGRÁFICAS ${ }^{146}$}

AA.VV. Cuaderno de teatro andaluz del siglo XVI. REYES, Mercedes de los, BOLAÑOS, Piedad y otros... (eds.). Sevilla: Consejería de Cultura, Centro Andaluz de Teatro/Centro de Documentación de las Artes Escénicas de Andalucía, 2004.

ÁLVAREZ, Melquíades. «Discurso-Programa del Partido Reformista». Gijón: El Noroeste, 12-IV-1912.

ARIAS CASTAÑÓN, Eloy. «Republicanismo y autonomía». Periódico La Alianza de Écija (1892-1893). En: Actas del III Congreso sobre el Andalucismo Histórico, Sevilla, 1989, pp. 651-668.

—. «Écija (1868-1874). De la revolución a la I República: aspectos de la vida política». En: Actas del I Congreso sobre Historia de Écija. Écija: Excmo. Ayuntamiento, 1989, pp. $329-375$.

—. «El contexto político de España en el Siglo XIX». En: Actas del Simposio Nacional. Literatura y Política en el siglo XIX. José María Gutiérrez de Alba. Sevilla: Centro Andaluz del Libro, 1998, pp. 15-50.

BLASCO IBÁÑEZ, Vicente. La bodega, CAUdET, Francisco (ed.). Madrid: Cátedra, 1998, p. 340.

—. «Discurso en la Universidad George Washington». En: Obras completas, $8^{\text {a }}$ ed., vol. IV, Madrid: Aguilar, 1987.

BOLAÑOS DONOSO, Piedad. «Cartelera teatral de Écija (1890-1899)». Signa. Revista de la Asociación Española de Semiótica, 16 (2007), pp. 235-288.

BOTREL, Jean-François. «El teatro en provincias bajo la Restauración. Un medio popular de comunicación». Bulletin Hispanique, 79 (1982), pp. 381-393; p. 383.

CANTOS, Marieta. «El teatro breve gaditano a mediados del siglo XIX: algunas piezas andaluzas de José Sanz Pérez». En: Casticismo y Literatura en España. PÉREZ-BUSTAMANTE, Ana Sofía y ROMERO FERRER, Alberto (eds.); VÁZQUEZ RECIO, Nieves (col.). Cuadernos Draco. Cádiz: Servicio de Publicaciones, 1992, pp. 99-116.

CASTELLÓN, Antonio. El teatro como instrumento político en España (1895-1914). Madrid: Textos Universitarios, Endimión, 1994.

CORTÉS IBÁÑEZ, Emilia. El teatro en Albacete en la segunda mitad del siglo XIX. 1999.

ESPÍN TEMPLADO, María Pilar. El teatro por horas en Madrid (1870-1910). Madrid: Instituto de Estudios Madrileños / Fundación Jacinto e Inocencio Guerrero, 1995.

${ }^{146}$ En esta Bibliografía sólo se han recogido los estudios. Las obras de creación estudiadas vienen referenciadas en las notas a pie de página. 
FERNÁNDEZ, María del Pilar. «Compañías y obras: notas para una aproximación al teatro canario del siglo XIX». En: Historia y crítica del teatro de comedias del siglo XIX... Y la burguesía también se divierte. El Puerto de Sta. María: Fundación Pedro Muñoz Seca, 1995, pp. 282-287.

FERNÁNDEZ GARCÍA, Estefanía. León y su actividad escénica en la segunda mitad del siglo XIX. Madrid: UNED, 1998.

FERNÁNDEZ INSUELA, Antonio. «Galdós y el drama social». En: AA.VV. Historia del teatro español. HUERTA CALVO, Javier (dir.). Madrid: Gredos, T. II, 2003.

GARCÍA LORENZO, Luciano. «La denominación de los géneros teatrales en España durante el siglo XIX y el primer tercio del siglo XX». En: Segismundo, 3 (1967) pp. 191-199.

GONZÁLEZ FERNÁNDEZ, Ángeles. «Una aproximación a los movimientos sociales en la Andalucía rural: Écija: 1900-1924», Écija en la Edad Contemporánea: En: Actas del V Congreso de Historia. Écija, Excmo. Ayuntamiento de Écija, 2000, pp. 461-479.

LÓPEZ CABRERA, María del Mar. El teatro en Las Palmas de Gran Canaria (18531900).Madrid: UNED, Tesis Doctoral, 1994/95. Editada en FUE, 2003.

LÓPEZ RUBIO, José. «La Restauración y su teatro». En: La Restauración Monárquica de 1875 y la España de la Restauración. Real Monasterio del Escorial: Biblioteca la Ciudad de Dios, 1978. Volumen conmemorativo del I Centenario de la Fundación del Real Colegio de Alfonso XII (1875-1975).

LOZANO GUIRAO, Pilar. «Vida y obra de Javier de Burgos». Revista de Literatura, XXVIII, 55-56 (1965), pp. 39-64.

MARTÍN OJEDA, Marina. «La casa de los Niños Expósitos de Écija (1602-1617)». En: Luis Vélez de Guevara, IV Congreso de Historia de Écija. BOLAÑOS, Piedad y Martín, M. (eds.), Sevilla: Excmo. Ayuntamiento y Fundación El Monte, 1996, pp. 365-378.

MARTÍNEZ SAN CELEDONIO, Félix Manuel y RINCÓN ALONSO, M. ${ }^{a}$ Jesús del. El teatro en Calahorra. Calahorra: Diputación, 2002.

MEJÍAS ÁLVAREZ, Jesús. «Ideas arquitectónicas de Balbino Marrón y Ranero en Écija: su proyecto de escuelas para niños». En: Écija en la Edad Contemporánea. Actas del V Congreso de Historia. Écija: Excmo. Ayuntamiento de Écija, 2000, pp.149-156.

MONLEÓN, José. «El autor y el público». Revista Drama, Otoño 2006, pp. 4-11.

PASCUAL MARTÍNEZ, Pedro. "Parlamento y teatro en el siglo XIX», en Historia y crítica del teatro de comedias del siglo XIX... Y la burguesía también se divierte. El Puerto de Santa María: Fundación Pedro Muñoz Seca, 1995.

PINO JIMÉNEZ, Fernando del. «Sobre la Juventud. Revista ecijana de intereses materiales, ciencias, literatura y costumbres. Enero-julio de 1868». En: Écija en la Edad Contemporánea. Actas del V Congreso de Historia. Écija: Excmo. Ayuntamiento, 2000, pp. 247-258.

QUIRÓS MATEO, José Antonio Bernardo de. Teatro y actividades afines en Ávila (siglo XVII, XVIII y XIX). Madrid: UNED, Tesis Doctoral, 1993/94. Editada en 2003.

REYES PEÑA, Mercedes de los y REYES CANO, Rogelio. «Algunas muestras de la relación 'Política-teatro' durante el sexenio absolutista en Sevilla (Datos para una historia del teatro en Sevilla en el siglo XIX)». Sevilla: Archivo Hispalense, 206 (1984), pp. 41-62.

ROCA, León. Vicente Blasco Ibáñez. Valencia: Ayuntamiento de Valencia, 1997.

RODRÍGUEZ SÁNCHEZ, Tomás. Catálogo de dramaturgos españoles del siglo XIX. Madrid: Fundación Universitaria Española, 1994.

ROMERO FERRER, Alberto. Catálogo de autores dramáticos andaluces: 1800-1897, 2 vols., VARGAS-ZÚÑIGA, Lola (dir.) y BAJO MARTÍNEZ, María Jesús (coord.). Sevilla: Consejería de Cultura/Centro de Documentación de las Artes Escénicas de Andalucía, 2002.

RUBIO JIMÉNEZ, Jesús. «Melodrama y teatro político en el siglo XIX. El escenario como tribuna política». Castilla, vol. 14, 1989, pp. 129-149.

—. La renovación teatral española de 1900: manifiestos y otros ensayos. Madrid: Publicaciones de la Asociación de Directores de Escena de España. Serie «Debate», núm. 8, 1998. 
SIMÓN PALMER, M. ${ }^{a}$ del Carmen. «La prensa local como fuente de la 'pequeña' historia». En: La prensa española durante el siglo XIX. Almería: Instituto de Estudios Almerienses, 1987.

SORIA GONZÁLEZ, A. Pequeña historia del Casino de Artesanos de Écija. Écija: Excmo. Ayuntamiento de Écija, 1982.

SUÁREZ CORTINA, Manuel. El gorro frigio. Liberalismo, Democracia y Republicanismo en la Restauración. Madrid: Biblioteca Nueva. Sociedad Menéndez Pelayo, 2000.

TORRENTE BALLESTER, Gonzalo. Teatro Español Contemporáneo. Madrid: Guadarrama, 1957.

VALENZUELA CANDELARIO, José. Pobreza y asistencia benéfica. El hospital de San Sebastián de Écija, 1813-1942. Sevilla: Secretariado de Publicaciones de la Universidad de Sevilla, 1996.

Fecha de recepción: 4 de julio de 2007

Fecha de aceptación: 24 de febrero de 2008 